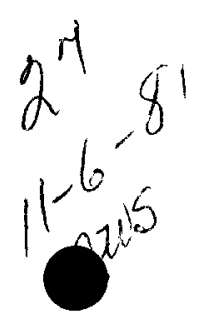

\title{
A SUMMARY OF THE \\ ENGINEERING ASSESSMENT OF \\ INACTIVE URANIUM MILL TAILINGS
}

\section{SPOOK SITE \\ CONVERSE COUNTY, WYOMING}

OCTOBER 1981

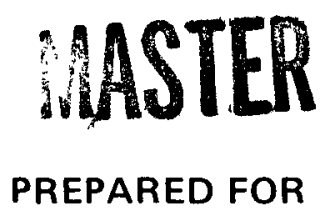

UNITED STATES DEPARTMENT OF ENERGY

ALBUQUERQUE OPERATIONS OFFICE

URANIUM MILL TAILINGS

REMEDIAL ACTIONS PROJECT OFFICE

ALBUQUERQUE, NEW MEXICO

CONTRACT NO. DE-AC04-76GJ01658

\section{BY

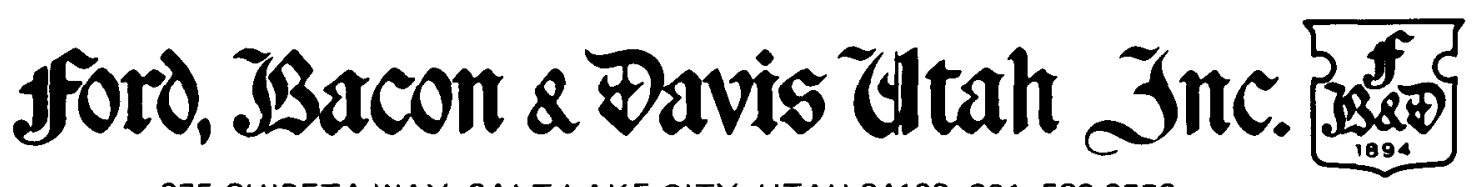

375 CHIPETA WAY, SALT LAKE CITY, UTAH 84108801 583-3773 


\section{DISCLAIMER}

THIS REPORT WAS PREPARED AS AN ACCOUNT OF WORK SPONSORED BY THE UNITED STATES GOVERNMENT. NEITHER THE UNITED STATES NOR THE UNITED STATES DEPARTMENT OF ENERGY, NOR ANY OF THEIR EMPLOYEES, MAKES ANY WARRANTY, EXPRESS OR IMPLIED, OR ASSUMES ANY LEGAL LIABILITY OR RE. SPONSIBILITY FOR THE ACCURACY, COMPLETENESS, OR USEFULNESS OF ANY INFORMATION, APPARATUS, PRODUCT, OR PROCESS DISCLOSED. OR REPRESENTS THAT ITS USE WOULD NOT INFRINGE PRIVATELY OWNED RIGHTS. REFERENCE HEREIN TO ANY SPECIFIC COMMERCIAL PRODUCT, PROCESS OR SERVICE BY TRADE NAME MARK, MANUFACTURER OR OTHERWISE, DOES NOT NECESSARILY CONSTITUTE OR IMPLY ITS ENDORSEMENT, RECOMMENDATION, OR FAVORING BY THE UNITED STATES GOVERNMENT OR ANY AGENCY THEREOF. THE VIEWS AND OPINIONS OF AUTHORS EXPRESSED HERE DO NOT NECESSARILY STATE OR REFLECT THOSE OF THE UNITED STATES GOVERNMENT OR ANY AGENCY THEREOF. 


\section{DISCLAIMER}

This report was prepared as an account of work sponsored by an agency of the United States Government. Neither the United States Government nor any agency Thereof, nor any of their employees, makes any warranty, express or implied, or assumes any legal liability or responsibility for the accuracy, completeness, or usefulness of any information, apparatus, product, or process disclosed, or represents that its use would not infringe privately owned rights. Reference herein to any specific commercial product, process, or service by trade name, trademark, manufacturer, or otherwise does not necessarily constitute or imply its endorsement, recommendation, or favoring by the United States Government or any agency thereof. The views and opinions of authors expressed herein do not necessarily state or reflect those of the United States Government or any agency thereof. 


\section{DISCLAIMER}

Portions of this document may be illegible in electronic image products. Images are produced from the best available original document. 
DOE/UMT-0119S

FBDU $-360-15 S$

UC 70

\author{
A SUMRARY OF THE \\ LIVGINEERING ASSESSHEN'I' \\ OF INACTIVE URANIUM MILL 'PAILINGS
}

SPOOK SITE

CONVERSE COUNTY, WYOMING

Octover 1981

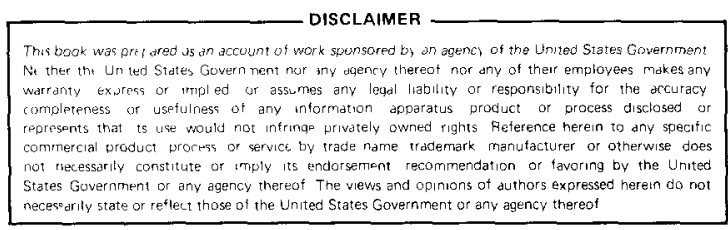

Prepared for

U.S. DEPARTMENT OF ENLRUYY ALBUQUERQUE JPERATIONS OFFICE

URANIUM MILL 'TAILINGS REMLDIAL ACTIONS PROJECT OFF'ICE

ALBUQUERQUE, IJEW MEXICO

Contract NO. DE-ACO4-76GJO1658

By

FORD, BACON \& DAVISS UPAH INC.

375 Chipeta Way

salt Lake City, Utah 8410 s 


\section{ITOT ICE}

This engineering assessment has been performed under DOE Contract NO. DE-ACO4-76GJOl658 between the U.S. Department of Energy and Ford, Bacon \& Davis Utah Inc.

Copies of this report may be obtained from the Uranium Mill Tailings Remedial Action Project Office, U.S. Department of Energy, Albuquerque operations Office, Albuquerque, New Mexico 37115. 


\section{FOREWORD}

This report is a sumnary of a parent report (issued under separate cover), entitled "Engineering Assessment of Inactive Uranium Mill Tailings for Spook Site, Converse County, Wyoring." Both reports have been authorized by the U.S. Department of Energy (DOE), Aliuquerque operations uffice, Uranium Mill Tailings Rernedial Action project office, Albuquerque, New Mexico, under Contract No. DE-AC04-76GJO1658. These reports are revisions of an earlier report dated December 1977, entitled "Phase II - Title I Engineering Assessment of Inactive Uranium Mill Tailings, Spook Site, Converse County, Wyoming," which was authorized by DOE, Grand Junction, Colorado, under Contract No. $E(05-1)-1658$.

These reports nave become necessary as a result of changes that have occurred since 1977 which pertain to the spook site and vicinity, as well as changes in remedial action criteria. The new data reflecting these changes are summarized in this report. Evaluation of the current conditions is essential to assessing the impacts associated with the options suggested for remedial actions for the tailings.

Ford, Bacon \& Davis Utan Inc. (FB\&DU) has received excellent cooperation and assistance in obtaining new data to prepare these reports. Special recognition is due Richard $H$. Campbell and wark Matthews of DOE, as well as Dick Hornbuckle, property owner at the spook site. Several local, county, and state agencies and private individuals also contributed information. 


\section{ABSTRACT}

Ford, Bacon \& Davis Utah 1nc. has reevaluated the spook site in order to revise the December 1977 engineering assessment of the problems resultiny from the existence of radioactive uranium mill tailings 48 ini northeast of Casper, in Converse County, Wyominy. This engineering assessment has included the preparation of topographic maps, the performance of core drillings and radionetric measurements sufficient to determine areas and volumes of tailings and radiation exposures of individuals and nearoy populations, the investigations of site hydrology and rneteorology, and the evaluation and costing of alternative corrective actions.

Radon gas released from the 187,000 tons of tailings at the spook site constitutes the most significant environnental impact, although windblown tailings and external yamma radiation also are factors. The four alternative actions presented in this engineering assessment range from rullsite decontamination with the adaition of $3 \mathrm{~m}$ of stabilization cover material (option I), to removal of the tailings to remote disposal sites and decontamination of the tailings site (options II through IV). Cost estimates for the four options ranye frorn about $\$ 710,000$ for stabilization in-place, to about $\$ 1,950,000$ for disposal at a distance of about $15 \mathrm{mi}$.

Three principal alternatives for the reprocessing of the spook tailings were examined:

(a) Heap leaching

(b) ireatment at an existing mill

(c) Reprocessing at a new conventional mill constructed for tailings reprocessing

The cost of the uranium recovered would be about $\$ 40 / 1 \mathrm{~b}$ of $\mathrm{U}_{3} \mathrm{O}_{8}$ by treatment in an existing conventional plant. The spot market price for uranium was $\$ 25 / 1$ b early in 1981 . Therefore, reprocessing the tailings for uranium recovery night be economically feasible if they could be treated as supplementary feed to a nearby operating nill, provided the price of uranium returns to the 1978-1979 levels. 


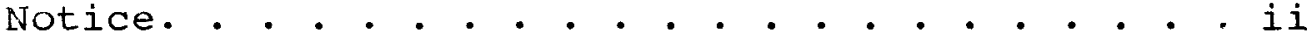

Foreword. . . . . . . . . . . . . . . . . iii

Aostract. . . . . . . . . . . . . . . . . iv

1 A SUIMMARY OF THE ENGINEERING ASSESSMENT

OF IIJACTIVE URANIUM LIILL TAILINGS . . . . . . . . 1-1

1.1 Introduction . . . . . . . . . . . 1-1

1.1.1 Backyround. . . . . . . . . . . . 1-2

1.1.2 Scope of Phase II Engineering

Assessment. . . . . . . . . . . . . 1-4

1.2 Site Description . . . . . . . . . . 1-6

1.2.1 Location and Topography . . . . . . 1-6

1.2.2 Ownership and History of Milling

Operations and Processing . . . . 1-6

1.2.3 Present Condition of the Site . . . 1-7

1.2.4 Tailings and Soil Characteristics . . 1-7

1.2.5 Geology, Hydrology, and

Meteorology . . . . . . . . . . 1-7

1.3 Radioactivity and Pollutant Impacts

on the Environment. . . . . . . . . . . 1-8

1.3.1 Radiation Exposure Pathways,

Contamination Mechanisms, and

Background Levels . . . . . . . 1-9

1.3.1.1 Radon Gas Diffusion and

Transport. . . . . . . . 1-9

1.3.1.2 Direct Gama Radiation . . . 1-10

1.3.1.3 Windblown Contaminants . . 1-10

1.3.1.4 Ground and surface water

Contamination. . . . . . 1-10

1.3.1.5 Soil Contamination. . . . 1-11

1.3.2 Rernedial Action Criteria. . . . . . 1-11

1.3.3 Potential Health Impact. . . . . . 1-13

1.3.4 Nonradioactive Pollutants . . . . . 1-15

1.4 Socioeconomic and Land Use Impacts . . . . 1-16

1.5 Recovery of Residual Values. . . . . . . . 1-16

1.6 Mill Tailings Stabilization. . . . . . . . . 1-17

1.7 Off-Site Remedial Action . . . . . . . . 1-18 


\section{TABLE OF CONTELTS (COnt)}

1.8 Disposal Site Selection. . . . . . . . . 1-18

1.9 Remedial Actions and Cost-Benefit

Analyses . . . . . . . . . . . . . . 1-18

1.9.1 Renedial Action Options . . . . . . 1-18

1.9 .2 Cost-Benefit Analyses . . . . . . 1-19

Table $1-1 \quad$ Sunuary of Conditions Noted

at Time of 1980 Site Visits. . . 1-20

Table 1-2 Summary of Remedial Action

Options and Effects. . . . . . . 1-22

Chapter 1 References. . . . . . . . . . . . 1-24

ADDENDUM, FTGURES AND TABLES. . . . . . . . . 1-25 
CHAPTER 1

A SUMMARY OF THE ENGINEERING ASSESSMEN'T OF IINACTIVE URANIUM MILL TAILINGS 
CHAPTER 1

\section{A SUMMAKY OF THE EIJGINEERING ASSESSMENT \\ OF INAC'TIVE URANIUM MILL TAILINGS}

\subsection{IITTRODUCTION}

The U.S. Energy Research and Developrnent Administration (ERDA) contracted in 1975 with Ford, Bacon \& Davis Utah Inc. (FB\&DU) of Salt Lake City, Utah, to provide architectengineering services and final reports based on the assessment of the problems resulting from the existence of large quantities of radioactive uranium mill tailings at inactive millsites in eight western states and in Pennsylvania. In 1980, the U.S. Department of Energy (DUE) contracted with FB\&DU to produce revised reports of the sites designated in the Uranium Mill Tailings Renedial Action (UMTRA) program in order to reflect the current conditions, new criteria and options, and to estinate current remedial action costs.

A preliminary survey (Phase I) was carried out in 1974 by the U.S. Atomic Energy Commission (AEC) in cooperation with the U.S. Environmental Prutection Agency (EPA) and the affected states. In a sumuary report, (1) ERDA identified 17 sites in Arizona, Colorado, Idaho, Wew wexico, Utah, and Wyoming for which practical remedial rueasures were to be evaluated. Subsequently, ERDA added five adcitional sites (Riverton and Converse County, Wyorning; Lakeview, uregon; Falls city and Ray Point, Texas). Hore recently, DuE has added a site in Canonsburg, Pennsylvania, one near Baggs, Wyoming, and two sites in North Dakota (Belfield and Bowman), and deleted Ray Point, for a total of 25 sites. DOE continues to investigate the status of the site near Baggs, Wyoming. Most of the mills at these sites produced by far the greatest part of their output of uranium under contracts with the AEC during the period 1947 through 1970. After operations ceased, some companies rade no attempt to stabilize the tailings, while others did so with varying degrees of success. Recently, concern has increased about the possible adverse effects to the general public from long-term exposure to low-level sources of radiation from the tailings piles and sites.

Prior to 1975, the studies of radiation levels on and in the vicinities of tnese sites were limited in scope. The data available were irsufficient to permit assessment of risk to people witn any degree of confidence. In addition, intormation on practicable measures to reduce radiation exposures and estimates of their projected costs was limited. The purposes of these recent studies performed by $F B \& D U$ have been to revise the information necessary to provide a basis for decision ruakiny for appropriate remedial actions for each of the 25 sites. 
Evaluations of the following factors have been included in this engineering assessment in order to assess the significance of the radiological conditions that exist today at the spook site:

(a) Exhalation of radon gas from the tailings

(b) On-site and off-site direct radiation

(c) Land contamination from windblown tailings

(d) Hydrology and contamination by water pathways

(e) Potential health impact

(f) Potential for extraction of additional minerals from the tailings

Investigation of these and other factors originally led to the evaluation of two potential practicable remedial action alternatives. Since that tine, these alternatives have been judged unacceptable because of new criteria that have been proposed. In this report, the remedial action alternatives are revised as follows:

(a) Option I - Stabilization of tailings at bottom of open pit, with a 3-m cover

(b) Option II - Removal of tailings to an unspecified site located $5 \mathrm{mi}$ from the spook tailings site

(c) Option III - Removal of tailings to an unspecified site located $10 \mathrm{mi}$ from the spook tailings site

(d) Option IV - Removal of tailings to an unspecified site located $15 \mathrm{mi}$ from the spook tailings site

In addition, if uranium prices were to rise from their presently depressed levels, it could be feasible to process the Spook tailings at the Bear creek mill, which lies only $2.5 \mathrm{mi}$ north of the spook tailings site.

\section{$\underline{1.1 .1 \quad \text { Background }}$}

On March 12, 1974, the Subcomnittee on Raw Waterials of the Joint Committee on Atomic Energy (JCAE), Congress of the United States, held hearings on S. 2566 and H.R. 11378, identical 
bills submitted by Senator Frank E. Moss and Representative Wayne owens of Utah. The bills provided for a cooperative arrangement between the ALC and the State of Utah in the area of the Vitro tailings site in Salt Lake City.* The bills also provided for the assessment of an appropriate remedial action to limit the exposure of individuals to radiation from uranium mill tailings.

Dr. William D. Rowe, testifying on benalf of the EPA, pointed out that there are other sites with similar problems. He recommended the problem be approached as a generic one, structured to address the most critical problem first.

Dr. Janes L. Liverman, testifying for the AEC, proposed that a comprehensive study should be made of all such piles, rather than treating the potential problem on a piecemeal basis. He proposed that tne study be a cooperative two-pnase undertakiny by the states concerned and the appropriate federal agencies, such as the AEC and EPA. Phase I would involve site visits to determine such aspects as their condition, ownership, proximity to populated areas, prospects for increased population near the site, and need for corrective action. A preliminary report then would be prepared which would serve as a basis for determining if a detailed engineering assessment (Phase II) were necessary for each millsite. The Phase II study, if necessary, would include evaluation of the problems, examination of alternative solutions, preparation of cost estimates and of detailed plans and specifications for alternative remedial action measures. This part of the study would include physical measurements to determine exposure or potential exposure to the public.

The Phase I assessment began in May 1974, with teams consisting of representatives of the ALC, the EPA, and the states involved visiting 21 of the inactive sites. 'The Phase I report was presented to the JCAE in october 1974. Table 1-1, adapted from Reference 1, summarizes the conditions in 1980 . Based on the findings presented in the Phase I report, the decision was made to proceed witn Phase II.

On May 5, 1975, ERDA, the successor to AEC, announced that Ford, Bacon \& Davis Utah Inc. of Salt Lake city, Utah, had been selected to provide the architect-engineering ( $A-\mathrm{E})$

\footnotetext{
*The proceedings of these hearings and the Summary Report on the Phase I study were published by the JCAE as Appendix 3 to ERDA Authorizing Legislation for Fiscal Year 1976. Hearings before the Subcommittee on Legislation, JCAE, on Fusion Power, Bionedical and Environmental Research; Operational Safety; Waste Management and Transportation, Feb 18 and 27, 1975, Part 2. The Phase I report on the spook site appears as Appendix I to Reference 4.
} 
services for Phase II. ERDA's Grand Junction, Colorado, Office (GJO) was authorized to negotiate and administer the terms of a contract with FB\&DU. The contract was effective on June 23, 1975. The Salt Lake City Vitro site was assigned as the initial task, and work began imnediately. Work at the spook site began on July 30, 1976, and the original Phase II - Title I Engineering Assessment was published in December 1977.(2)

On November 8, 1978, the Uranium Mill Tailings Radiation control Act of 1978 (PL 95-604) became effective. This legislation provides for state participation with the Federal Government in the remedial action for inactive tailings piles. Pursuant to requirements of PL 95-604, the EPA has the responsibility to promulgate remedial action standards for the cleanup of areas contaminated with residual radioactive material and for disposal of tailings. The U.S. Nuclear Regulatory Commission (INRC) has the responsibility for enforcing these standards.

In 1979, DOE established the UMTRA Program Office in Albuquerque, New Mexico. Work on the program has since been directed by personnel in that office. The supplementary field work by $F B \& D U$ in support of this report was performed during the week of July 21, 1980.

\subsubsection{Scope of Phase II Engineering Assessment}

Phase II A-E Services are diviued into two stages: Title I and Title II.

Title I services include the engineering assessment of existing conditions and the identification, evaluation, and costing of alternative remedial actions for each site. Following the selection and funding of a specific remedial action plan, Title II services will be performed. These services will include the preparation of detailed plans and specifications for implementation of the selected remedial action.

This report is a continuation of the assessment rade for Title I requirements and has been prepared by FB\&DU. In connection with the field studies made in 1976, the Oak Ridge National Laboratory (ORIL) at Oak Ridge, Tennessee, under separate agreement with DUE, provided measurements of the radioactivity concentrations in the soil and water samples and gamma surveys. The EPA staff provided the results of radiation surveys they previously nad made at the spook site.

The specific scope requirements of the Title I assessment may include but are not linited to the following:

(a) Preparation of an engineeriny assessment report for each site, and preparation of a comprehensive report suitable for submission to the congress on 
reasonable remedial action alternatives and their estimated cost.

(b) Determination of property ownership in order to obtain release of Federal Government and A-E liability for performance of engineering assessment work at both inactive millsites and privately owned structures.

(c) Preparation of topographic maps of millsites and other sites to which tailings and other radioactive materials might be moved.

(d) Performance of core drillings and radiometric measurements ample to determine volumes of tailings and other radium-contaminated materials.

(e) Performance of radiometric surveys, as required, to determine areas and structures requiring cleanup or decontamination.

(f) Determination of the adequacy and the environmental suitability of sites at which nill tailings containing radium could be disposed; and once such sites are identified, perform evaluations and estimate the costs involved.

(g) Performance of engineering assessments of structures where uranium mill tailings have been used in off-site construction to arrive at recommendations and estimated costs of performing renedial action.

(h) Evaluation of various methods, techniques, and materials for stabilizing uranium mill tailings to prevent wind and water erosion, to inhibit or eliminate radon exhalation, and to minimize maintenance and control costs.

(i) Evaluation of availability of suitable fill and stabilization cover materials that could be used.

(j) Evaluation of radiation exposures of individuals and nearby populations resulting from the inactive uranium rillsite, with specific attention to:

(1) Gamma radiation

(2) Radon

(3) Radon daughter concentrations 
(4) Radium and other naturally occurring radioisotopes in the tailings

(k) Review of existing information about site hydrology and neteorology.

(1) Evaluation of recovering residual values, such as uranium and vanadium in the tailings and other residues on the sites.

(n) Performance of demographic and land use studies. Investigation of community and area planning, and industrial and growth projections.

(n) Ivaluation of the alternative corrective actions for each site in order to arrive at recommendations, estimated costs, and socioeconomic impact based on population and land use projections.

(o) Preparation of preliminary plans, specifications, and cost estimates for alternative corrective actions for each site.

Not all of these items received attention at the spook site.

\subsection{SITE DESCRIPTION}

1.2 .1 Location and ropography

The spook millsite and tailings pile are located approximately $48 \mathrm{mi}$ northeast of casper, in Converse County, Wyoming, and approximately $32 \mathrm{mi}$ northeast of Glemrock, wyoraing.

The site is located anong rolling hills at an elevation of about 5,100 ft above sea level in the drainage basin of the Cheyenne River. Vegetation is comprised of sagebrush and native grasses, with cottonwood trees along the creek bottoms. The site and its relationship to the surrounding area are shown in Figure $2-1 . *$

\subsubsection{Ownership and History of Milling Operations and Processing}

The Wyoring Mining and Milling Company operated on the site, which is owned by Richard T. Hornbuckle, Pearl R. Hornbuckle, Kirkwood T. Hornbuckle, and Brent B. Hornbuckle.

\footnotetext{
*Figures and tables referenced in this summary are extracted from Chapters 2 through $y$ of tne parent report and are in tne addendum.
} 
Western Nuclear, Inc., a subsidiary of Phelps Dodge Corporation, is presently responsible for the property.

The upgrader became operational in 1962 and ran until June 1965. Ore from the adjacent open-pit mine averaged 0.128 $\mathrm{U}_{3} \mathrm{O}_{8}$, and ajout 187,000 tons were processed. (Some ore was shipped directly to a mill at Jeffrey City, wyoming.) The ore was acid-leached and the uranium slurry was trucked $165 \mathrm{mi}$ to the western Nuclear mill at Jeffrey City for further processing.

1.2.3 Present Condition of the site

Figure 2-5 is a descriptive map of a portion of the site as it now exists. The major structures have been removed. Concrete foundations, machine parts, timbers, overhead electrical equipment, and crusher components remain. The 187,000 tons of tailings rest on the top edge, side slope and bottom of the open-pit mine, and cover about 5 acres. They have not been stabilized and show some signs of water erosion. The most prominent features of the site are the open-pit mine and adjacent pile of mine waste and mine overburden. The pit is approximately $100 \mathrm{ft}$ deep in its deepest point. Figure 2-6 is a cross-section through the tailings pile and mine pit.

About half the surface area of the tailings site is covered by weeds and native grasses. A barbed wire fence surrounds the millsite, open-pit rnine, overburden, and tailings areas. A haul road runs north and south imnediately to the west of the site; the road is used to haul ore from open-pit mines south of the site to a processing plant $2.5 \mathrm{mi}$ to the north of the site.

\subsubsection{Tailings and Soil Characteristics}

The tailings are sandy in character, altnough no measurements of physical properties were performed. The soil on the site is a thin layer of weathered sandstone from the bedrock beneath the site.

1.2 .5 Geology, Hydrology, and Meteorology

The spook tailings pile, millsite, and the spook mine are located on the slopes of a rolling hillside typical of the southern margin of the Powder River Basin. Bedrock is exposed in the open pit and consists of sandstones and shales of the Monument Hill unit of the wasatch Formation. The Wasatch Formation is underlain by up to 2,000 ft of sandstones and shales of the Fort Union Formation. The shale and claystone units of the formations act as confining layers that prevent the upward and downward migration of ground waters. Although the strata at the site are virtually flat-lying, regional correlation suggests a very gentle dip of less than 1 deg to the north. A simplified stratigrapnic column is shown in Figure 2-7. 
The surface waters on or near the site consist of standing water in the pit during some months of the year, an interceptor ditch that diverts storm runoff around the tailings and pit, ephermeral drainage channels, and an intermittent stream south of the pile known as the Dry Fork Cheyenne River. Off-site contamination of surface waters by physical transport of tailings or by chemical leaching is unlikely. This is due to the distance of flowing surface waters from the site, the gentle hydraulic gradient, and the topograpny and drainage system at the site which limits almost all off-site runoff from reaching the tailings and allows only the precipitation that falls on the site to collect in the pit.

The aquifers of the Powder River Basin System are typically at different depths within the wasatch and Fort Union Formations, and their water quality and quantity vary considerably. Most of the wells in the area are completed at depths of less than $300 \mathrm{ft}$. Some of these are flowing wells, others are purmed. In recent years, many of the shallow wells have dried out or slowed down in flow rates. During this time, mining companies have developed deep wells (greater than 1,000 ft) for use in their mining and process activities.

Regional recharge areas for the aquifers are the highland areas. Local recharge areas include higher areas such as the Cheyenne River Divide or locations where permeable formations are intercepted by surface waters. The spook Mine pit is in permeable strata and can act as a point for ground water recharge. However, this recharge potential is small due to the limited precipitation that is trapped on the site. should contamination occur due to the tailings, the effects would be mininal. Only stock water wells tap the nearby shallower aquifers. Furthermore, the strata of the pit are the host rock for the uranium ore of the vicinity and any contribution of radionuclides from the tailings would be far exceeded by natural sources.

The tailings are vulnerable to strong winds that are typical of the area and tend to blow from the southwest. Annual precipitation averages about $13 \mathrm{in}$. Thunderstorms are cornon occurrences and are sometimes accompanied by severe hail or tornado activity as well as by wind and rain.

\subsection{RADIOACTIVITY AND POLLUTANT IMPACTS ON THE ENVIRONMENT}

About $85 \%$ of the total radioactivity originally in uranium ore remained in the tailings after removal of the uranium. The principal environmental radiological impact and associated health effects arise from the $230_{\mathrm{Th}}, 226_{\mathrm{Ra}}, 222_{\mathrm{Rn}}$, and $222 \mathrm{Rn}$ daughters contained in the uranium tailings. Although these radionuclides occur in nature, their concentrations in tailings material are several orders of magnitude greater than their average concentrations in the earth's crust. Because of the 
chemical treatments these radionuclides have experienced, it appears that $226_{\mathrm{Ra}}$ is more soluble and, therefore, more mobile. $\frac{1.3 .1 \text { Radiation Exposure Pathways, Contamination Mechanisms, }}{\text { and Background Levels }}$

are:

The major potential environmental routes of exposure to man

(a) Inhalation of $222 \mathrm{Rn}$ and its daughter products, resulting from the continuous radioactive decay of $22 \sigma_{\mathrm{Ra}}$ in the tailings. Radon is a gas which diffuses from the pile. The principal exposure results from inhalation of $222 \mathrm{Rn}$ daughters. This exposure affects the lungs. For this assessment, no criteria have been established for radon concentrations in air. However, the pathway for radon and radon daughters accounts for the major portion of the exposure to the population.

(b) External whole-body gamua exposure directly from radionuclides in the pile.

(c) Inhalation and ingestion of windblown tailings. The primary health effect relates to the alpha enitters $230_{\mathrm{Th}}$ and $226_{\mathrm{Ra}}$, each of which causes exposure to the bones and lungs.

(d) Ingestion of yround and surface water contaminated with radioactive elements (primarily $\left.226_{\mathrm{Ra}}\right)$ and other toxic materials.

(e) Contanination of food through uptake and concentration of radioactive elements by plants and animals is another pathway that can occur; however, this pathway was not considered in this study.

\subsubsection{Radon Gas Diffusion and Transport}

Short-term radon measurements were performed by FB\&DU in 1976 with continuous radon monitors supplied by ERDA(3) at three locations in the vicinity of the spook tailings pile. The locations and values of the $24-\mathrm{hr}$ radon concentrations are shown in Figure 3-4. The highest outdoor radon concentration was measured on the pile $(17 \mathrm{pCi} / 1)$. Background atmospheric radon at a location $2 \mathrm{mi}$ from the site measured $1.1 \mathrm{pCi} / 1$. Radon above the average background level was detected at $0.4 \mathrm{mi}$ froll the site. 
The average external gamma radiation (EGR) within a few feet of the pit was about $128 \mu R / h r$. The highest EGR level, around $650 \mu \mathrm{R} / \mathrm{hr}$, was measured in the pit along a southwesterly traverse originating at the northwestern edge of the tailings pile. This high reading was also associated with a correspondingly high soil concentration of $226 \mathrm{Ra}$ and is probably due to residual ore.

In the area surrounding the tailings, the gamma radiation rates were greater than twice background due largely to the open-pit uraniun mine and mine waste. Beyond the mine and mine waste area, the gamma radiation decreased to background within $0.2 \mathrm{mi}$.

1.3.1.3 Windblown Contaminants

Prevailing winds in the area are from west-southwest. The results of the EPA gamma radiation survey around the tailings pile are shown in Figure 3-10. Figure 3-12 shows the locations ana measurements of $22 \sigma_{R a}$ along traverses throughout the site area. Not all of the apparent contamination is due solely to the presence of the tailings; the high natural background levels of uranium and radium, and the large quantities of radioactive overburden surrounding the millsite, almost certainly contribute to elevated levels of surface contamination at some distances away from the tailings. With this qualification in mind, the boundary of the area assumed to ve contaminated by tailings was drawn as shown in Figure 3-12.

1.3.1.4 Ground and Surface water Contamination

Three water samples were taken from the Dry Fork Cheyenne River, which is an intermittent strear. All of these samples (upstream, downstream, and at the confluence with a wash that drains the southern mine waste) contained $0.1,1.27$, and $0.16 \mathrm{pCi} / 1$ of $226_{\mathrm{Ra}}$, respectively.(4) All of these levels are below the EPA Interim Prinary Drinking Water Regulations for radioactive contaninants.

A water sample from a stagnant pond south of the tailings pile just off a pile of mine waste contained $21.7 \mathrm{pci} / 1$ of $226_{\mathrm{Ra}}$. However, this water has little chance of reaching the Cheyenne River. Two well water samples from wells south and east of the tailings contained 0.24 and $0.22 \mathrm{pCi} / 1$ of $226_{\mathrm{Ra}}$, respectively.

Considering the aistance between the tailings and a flowing strearn and the naturally occurring radioactivity in the area, the tailings have little potential for increasing the $226 \mathrm{Ra}$ content of off-site water. 
1.3.1.5 Soil Contamination

The leaching of radiun from the tailings into the subsoil averaged 3 ft but extends from 2 to 5 ft before reaching background levels of $226_{\mathrm{Ra}}$ concentration. The profile of radium concentration in the tailings was determined with a gamma probe and by core sample analyses. (4)

\subsubsection{Remedial Action Criteria}

For the purpose of conducting the original engineering assessment, (2) provisional criteria provided by the EPA were used. The criteria were in two categories, and applied either to structures with tailings present or to land areas to be decontaminated. For structures, the indoor radiation level below which no remedial action was indicated was considered to be an external gamna radiation level of less than $0.05 \mathrm{mR} / \mathrm{hr}$ above background and a radon daughter concentration of less than 0.01 WL above background. Land could be released for unrestricted use if the external gamma radiation levels were less than $10 \mu \mathrm{R} / \mathrm{hr}$ above background. When cleanup was necessary, residual radium content of the soil after remedial action should not exceed twice background in the area.

Since enactment of the Uranium Mill Tailings Radiation Control Act of 1978 (PL 95-604), which was effective November 8, 1978, the EPA has published interim (45 FR 27366) and proposed (45 FR 27370) standards for structures and open lands. 'Ihese standards establish the indoor radon daughter concentration, including background, below which no remedial action is indicated at $0.015 \mathrm{WL}$. The indoor gamma radiation limit is $0.02 \mathrm{mR} / \mathrm{hr}$ above background.

For open land, remedial action must proviăe reasonable assurance that the average concentration of $226_{\mathrm{Ra}}$ attributable to residual radioactive material from any aesignated processing site in any $5-\mathrm{cm}$ thickness of soils or other naterials within 1 ft of the surface, or in any $15-\mathrm{cm}$ thickness below $1 \mathrm{ft}$, shall not exceed $5 \mathrm{pCi} / \mathrm{y}$.

Environmental standards have been proposed by the EPA (46 FR 2556) for the disposal of residual radioactive materials from inactive uranium processing sites. These standards require that disposal of residual radioactive materials be conducted in a way which provides a reasonable assurance that for at least $1,000 \mathrm{yr}$ following disposal:

(a) The average annual release of $222 \mathrm{Rn}$ from the aisposal site to the atmosphere by residual radioactive naterials will not exceed $2 \mathrm{pCi} / \mathrm{m}^{2}-\mathrm{s}$.

(b) Substances released from residual radioactive materials after disposal will not cause: 
(1) the concentrations of those substances in any underground source of drinking water to exceed the level specified below, * or

(2) an increase in the concentrations of those substances in any underground source of drinking water where the concentrations of those substances prior to remedial action exceed the levels specified below for causes other than residual radioactive materials.*

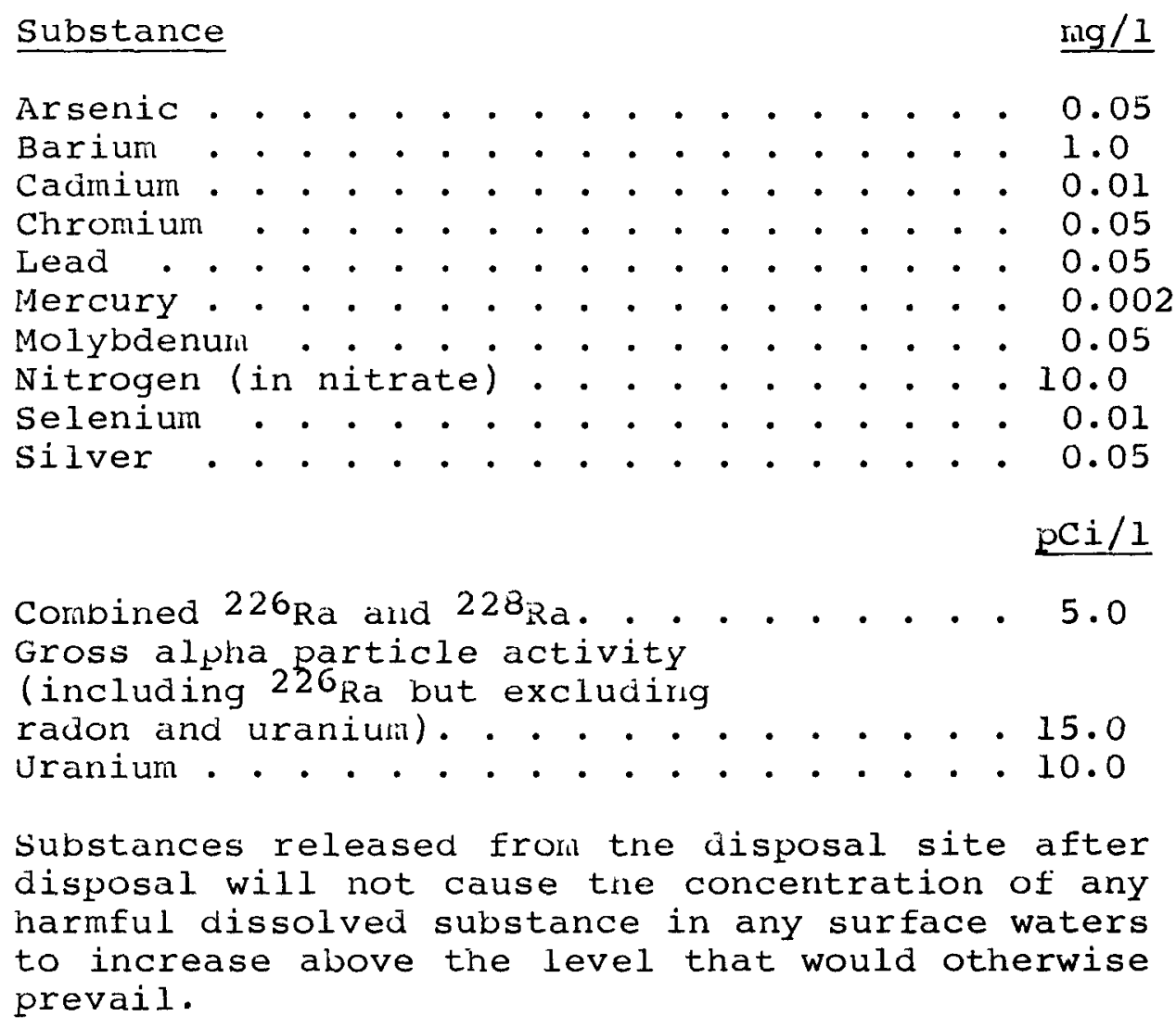

Since the passage of PL 95-604, the NRC has publisned final regulations for uranium nill tailings licensing in the Federal Register (45 FR 65521). They include the requirement that the stabilization method must include an earth cover of at least a 3-In thickness and sufficient to reduce the radon emanation rate from the tailings to less than $2 \mathrm{pCi} / \mathrm{m}^{2}-\mathrm{s}$ above background. In addition, seepaye of materials into ground water should be reduced by design to the maximum extent reasonably achievable.

*These requirements apply to the dissolvea portion of any substance listed above at any distance greater than $1.0 \mathrm{~km}$ from a disposal site that is part of an inactive processing site, or greater than $0.1 \mathrm{~km}$ if the disposal site is a depository site. 
While these standards may undergo further revisions, the interim and proposed standards as indicated above form the basis for determining required remedial actions and their associated costs.

\subsubsection{Potential Health Impact}

Radon gas exhalation from the pile and the subsequent inhalation of radon daughters account for most of the total dose to the population from the spook site under present conditions. The gatnma radiation exposure from the spook pile is virtually zero past $0.2 \mathrm{mi}$. There are few people who live or work within 1.5 mi of the pile, where ganua radiation is above background.

Gamna radiation can be reduced effectively by shielding with any dense naterial. However, experience has shown that it is very difficult to control the movement of radon gas througn porous materials. Once released from the radium-bearing minerals in the tailings, the gaseous radon diffuses by the path of least resistance to the surface. rhe radon has a half1 ife of about 4 days, and its daughter products are solids. Therefore, part of the radon decays ell route to the surface and leaves daughter products witnin the tailings pile. If the diffusion time can be made long enough, tnen, theoretically, virtually all of the radon and its daughter products will nave decayed before escaping to the atmosphere. Calculations using the theoretical techniques of Kraner, Schroeder, and Evans $(5)$ earlier indicated that $13 \mathrm{ft}$ of earth cover would pe required to reduce the radon diffusion from the Spook tailings by 958 . Later experimental work $(6)$ has demonstrated that 2 to $3 \mathrm{ft}$ of compacied clay may ve sufficient to reduce radon flux to less than $2 \mathrm{pCi} / \mathrm{m}^{2}-\mathrm{s}$, assuming the continued integrity of the clay cover.

The health significance to man of long-term exposure to low-level radiation is a subject that has been studied extensively. Since the end results of long-term exposure to low-level radiation may be diseases such as lung cancer or leukemia, which are also attributable to many other causes, the determination of specific cause in any yiven case becones very difficult. Therefore, the usual approach to evaluation of the health impact of low-level radiation exposures is to make projections from observed eifects of high exposures on the premise that the effects are linear. A considerable amount of information has been accumulated on the high incidence of lung cancer in uranium miners and others exposed to radon and its daugnters in mine air. 'This provides a basis for calculating the probable health effects of low-level exposure to large populations. (The term "health effect" refers to an incidence of aisease; for radon daughter exposure, a nealth effect is a case of lung cancer.) This is tne basis of the health effects calculated in this report. It should be recognized, however, that there is a larye deyree of uncertainty in such 
projections. Among the complicating factors is the combined effect of radon daughters with other carcinogens. As an example, the incidence of lung cancer arnong uranium miners who smoke is far higher than can be explained on the basis of either smoking or the radiation alone.

The risk estimators used in this report are given in the report of the iNational Academy of sciences Advisory Committee on the Biological Effects of Ionizing Radiation (BEIR-III report). (7) This report presents risk estimators for lung cancer derived from epidemiological studies of both uranium miners and fluorspar miners. The average of the age-dependent absolute risk estintator for these two groups as applied to the population at large is 150 cancers per year per $10^{6}$ person-WLM of continuous exposure, assuming a lifetime plateau to age 75. The term WLM means working level months, or an exposure to a concentration of one working level of radon daughter products in air for $170 \mathrm{hr}$, which is a work-month. A working level (WL) is a unit of measure of radon daughter products which recognizes that the several daughter elements are frequently not in equilibrium with each other or with the parent radon. Because of the many factors that contribute to natural biological variability and of the many differences between exposure conditions in mines and residences, this estimator ( 150 cancer cases per year per $10^{6}$ person-WLM of continuous exposure) is considered to have an uncertainty factor of about 3. Another means of expressing risk is the relative risk estimator, which yields risk as a percentage increase in health effects per $10^{6}$ person-ivlm of continuous exposure. However, this metnod has been shown to be invalid( 8 ) and is not considered in this assessment.

For the purpose of tinis engineering assessment, it was assurned that about 508 equilibrium exists inside structures between radon and its dauginter elements resulting in the following conversion tactors:

$$
1 \mathrm{pCi} / 1 \text { of } 222 \mathrm{Rn}=0.005 \mathrm{WL}
$$

For continuous exposure:

$$
0.005 \mathrm{WL}=0.25 \mathrm{WLM} / \mathrm{Yr}
$$

On the basis of predictions of radon concentrations in excess of the background value under present conditions, it was calculated that the average lung cancer risk attributable to radon released from the tailings pile in the vicinity within $4.5 \mathrm{ni}$ of the spook site is $2.6 \mathrm{x} 10^{-8}$ per person per year, or less than $0.02 \%$ of the average lung cancer risk due to all causes for wyoming residents $\left(2.1 \times 10^{-4}\right) .(9)$ 
The 25-yr health effects were calculated for three population projections using the present population of 86 in the o- to 4.5-mi area. The results for pile-induced radon and background radon for the area ( 0 to $4.5 \mathrm{mi})$ were as follows:

25-Year Cumulative Health Effects Within 4.5 Miles of Edge of Pile

Projected Population Growth

Constant $0.8 \%$ growth rate Constant $3 \%$ growth rate 8.88 declining growth rate*

\section{Pile-Induced RDC}

0.000063

0.000083

0.00013
Background RDC

0.10

0.13

0.20

\subsubsection{Nonradioactive Pollutants}

There are other potentially toxic materials in the tailings. Chemical analyses of tailings samples from auger holes in the spook pile showed barium, chromium, and lead in concentrations between 3 and $50 \mathrm{ppm}$. The highest selenium concentration was $270 \mathrm{ppm}$, and arsenic concentration was about $90 \mathrm{ppm}$. Vanadium was present at about 26 to $350 \mathrm{ppm}$. It has been speculated that high concentrations of selenium in the overburden, resulting in correspondingly high levels of that element in the vegetation, were responsible for the deaths of cattle grazing on site about 12 to 15 yr ago.

Six water samples were taken from the vicinity of the spook site and chemically analyzed; four samples from stagnant ponds south of the millsite, and two ground water samples from wells east and south of the site. The locations of these samples are shown in Figure 3-11 and the analyses of these samples are presented in Table 3-4. All water samples contained selenium above the EPA Interim Primary Drinking Water Regulations. In addition, some of the samples contained arsenic and cadmiun above the drinking water regulations.

While there is some water contamination near the spook mine and millsite, it is mainly due to mine waste and not mill tailings. The tailings have been deposited within the open-pit mine and precipitation which falls on the tailings is mostly confined in the pit. The possibility of seepage from the pile degrading the surface water quality is unlikely because of the distance from the tailings to flowing surface waters and other natural sources of contamination.

*Declines linearly from its initial value to zero in 25 yr and remains constant at zero thereafter. 


\subsection{SOCIOECONOMIC AIND LAND USE IMPACTS}

Except for the mineral, oil, and gas exploration and development near the site, virtually all the land near the tailings site is used for grazing. A haul road just west of the site is used regularly for transporting ore to the Bear Creek uranium millsite, a few miles north of the site. The population centers closest to the site are some 30 to $40 \mathrm{mi}$ south of the site. There is only one ranch house within 2 mi of the site, and there are about 90 persons living within $15 \mathrm{mi}$ of the site. The land surrounding the site is all in private ownership.

There is ongoing drilling and exploration for minerals within the area. Two local mining companies intend to mine adjacent to the northern and eastern boundaries of the site.

The presence of the tailings restricts the use of the site to only a minor degree. The acreage occupied by the tailings is less than 5 acres, most of which is adjacent to an open-pit mine. This loss is minimal compared with the much larger area occupied by the open pit, mine waste, and overburden piles. If the tailings were not present, there would be virtually no change in land uses and values in the surrounding areas.

\subsection{RECOVERY OF RESIDUAL VALUES}

Available historical records that provide reliable data on specific mineral contents of the spook tailings site are limited. Only a few samples of tailings were obtained during this study. Consequently, calculations based on these samples would not be statistically representative. Estimates of the spook tailings from AEC records show an average of $0.0238 \mathrm{U}_{3} \mathrm{O}_{8}$.

There are, however, five factors that can be considered to evaluate whether reprocessing spook tailings to extract uranium and other mineral values would be practicable:

(a) The amount of tailings present

(b) Concentrations of residual values

(c) Projected recovery

(d) Current market price of recovered values

(e) Proximity to processing rilis

Three principal alternatives for the reprocessing of the Spook tailings were examined: 
(a) Heap leaching

(b) Treatment at an existing mill

(c) Reprocessing at a new conventional mill constructed for tailings reprocessing

The cost of the uranium recovered would be about $\$ 40 / 1 \mathrm{~b}$ of $\mathrm{U}_{3} \mathrm{O}_{8}$ by treatment in an existing conventional plant. The spot market price for uranium was $\$ 25 / 1 b$ early in 1981. Therefore, reprocessing the spook tailings for uranium recovery might be economically feasible if they were treated as supplementary feed to a nearby operating mill. Construction of reprocessing facilities for the sole purpose of reprocessing the spook tailings would be infeasible due to the quantity and grade of the tailings.

\subsection{MILL TAILINGS STABILIZATION}

Investigations of methods of stabilizing uranium mill tailings piles from wind and water erosion have indicated a variety of deficiencies among the methods. Chemical stabilization (treatment of the tailings surface) has been successful only for temporary applications and is thus viewed as inadequate for currently proposed aisposal criteria. Volumetric chemical stabilization (soliaifying the bulk of the tailings) techniques appear to be costly and of questionable permanence. Physical stabilization (emplacement of covers over the tailings) methods using soil, clay, or gravel have been demonstrated on a laboratory scale to be effective in stabilizing tailings. Artificial cover materials are attractive uut have the disadvantage of being subject to degradation by natural and artificial forces. Vegetative stabilization (establishment of plant growth) methods are effective in limiting erosion. However, where annual precipitation is less than about $10 \mathrm{in.,}$ soil moisture content may be inadequate to ensure viability of the plant life.

Migration of contaninants into ground water systems must be limited under the NRC and EPA criteria. Control of water percolating through the tailings can be accomplished by stabilizing chemically, by physically compacting the cover material, and by contouring the drainage area and tailings cover surface. Isolation of the tailings from underlying ground water systems can be accomplished by lining a proposed disposal site with natural or artificial inpermeable membranes.

Several materials have been identified which sufficiently retard radon migration so that the radon flux is substantially reduced, on a laboratory scale. Unfortunately, no large-scale application has been undertaken which would demonstrate that these materials satisfy all of the technical criteria in the EPA-proposed standards and the iNRC regulations for licensing of 
uranium mills. However, extensive investigations of these questions continue in the Technology Development program of the Uranium Mill Tailings Remedial Actions Project office in Albuquerque, kew Mexico.

In view of findings from stabilization research, it appears that physical stabilization of tailings with $3 \mathrm{~m}$ of well-engineered cover material may be sufficient to appropriately stabilize tailings at their disposal site to meet NRC regulations.

\subsection{OFF-SITE REMEDIAL ACTION}

There are no off-site locations other than windolown where tailings have been used, and therefore no such areas to decontaminate.

It is difficult to assess windblown contamination attributable to the tailings pile alone since there are other prevalent radioactive sources in the vicinity. The estimated boundaries of windblown tailings are shown in Figure 9-1. The cost of cleanup of the estimated 11 acres of off-site land contaminated by windblown tailings is estinated to be $\$ 50,000$, exclusive of engineering and contingency allowances.

\section{I.8 DISPOSAL SITE SELPCTION}

In this report, three of the alternative remedial action options include moving the spook tailings to unspecified disposal sites. The responsibility for disposal site selection lies with the Federal Government, with input from the state. At such time as tentative selections are made, site-specific costs may be estimated.

In each disposal option, surface material would be removed, as appropriate, from the disposal area and stockpiled. A retaining dike and diversion ditches would be constructed if necessary. The tailings would be emplaced, contoured, and covered with $3 \mathrm{~m}$ of soil. The surface would be covered with $0.3 \mathrm{~m}$ of riprap or vegetation established for erosion control and the entire site fenced.

\subsection{REMEDIAL ACTIONS AND COST-BENEFIT AIJALYSES}

\subsubsection{Remedial Action Options}

The remedial action options exanined include stabilization of the tailings in the pit adjacent to the tailings site, and removal of all radioactive tailings naterials to areas where these materials could be isolated from the public. The options are summarized in Table 1-2. The basis for comparison, from which the cost effectiveness of remedial alternatives can be judged, is the present condition of the site witn no remedial action. 
Option I represents remedial action activities to stabilize the pile at the bottom of the open pit and with the addition of a 3-m depth of cover. Radon exhalation would be reduced to not Inore than $2 \mathrm{pCi} / \mathrm{m}^{2}-\mathrm{s}$ above background. The tailinys site would have limited future use.

Costs for tailings disposal at three unspecified sites at distances of 5, 10 , and 15 mi from the spook tailings were evaluated. Since the market for uranium is presently depressed, the possibility of reprocessing the tailings at the Bear Creek mill was not addressed, even though this mignt be an alternative solution if the price for uranium concentrate were to rise significantly.

\subsubsection{Cost-Benefit Analyses}

As summarized in Table 9-1, the total costs for the four remedial action options vary fron about $\$ 710,000$ to about $\$ 1,950,000$. Each of these options would have associated health and monetary benefits. The options are identified by number in Paragraph 1.1 .

The number of cancer cases avoided per million dollars expended for each option is given in Figure 9-2. The curves in Figure 9-2 indicate an increase in healtn benefit-cost ratio with time due to the greater reduction in population exposure over longer periods of time as a result of remedial action. The potential cancer cases avoided for each option and the cost per potential cancer case avoided are given in Table $9-2$.

As indicated in Chapters 2 and 3 , the mill and tailings site are located directly at the mine, and are adjoined by the open-pit mine and various piles of overburden which exhibit radioactivity levels well above the proposed standards for millsite and tailings pile stabilization. These mining wastes would continue to have an inpact on the contamination levels of the site and therefore on its future utility. However, the cleanup of radioactive contamination resulting from mining operations per se is a separate problem that is not within the scope of the remedial action activities described in this report. 
TABLE $1-1$

SUMMARY OF CONDITIONS NOTED AT TIME OF 1980 SITE VISITS

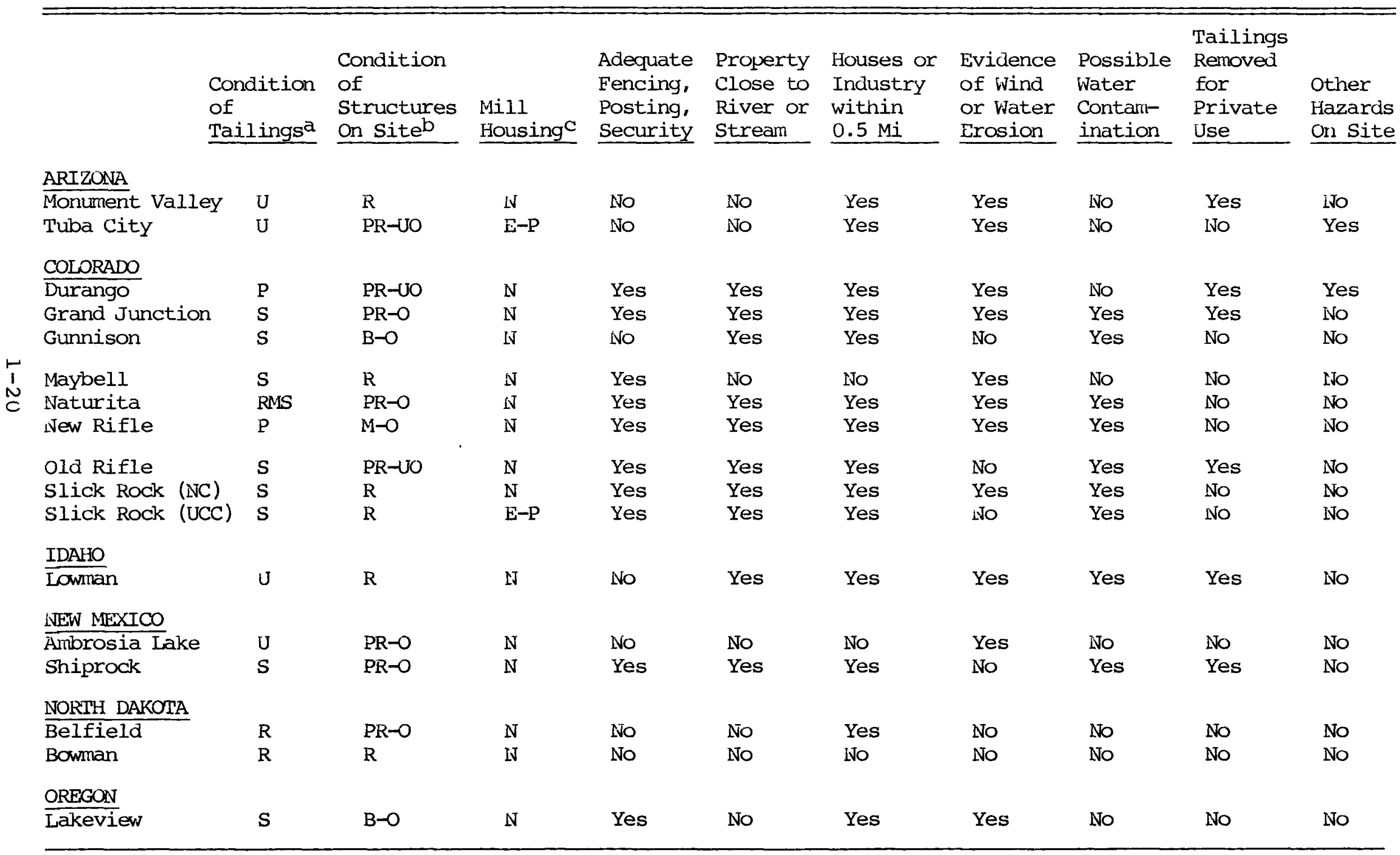




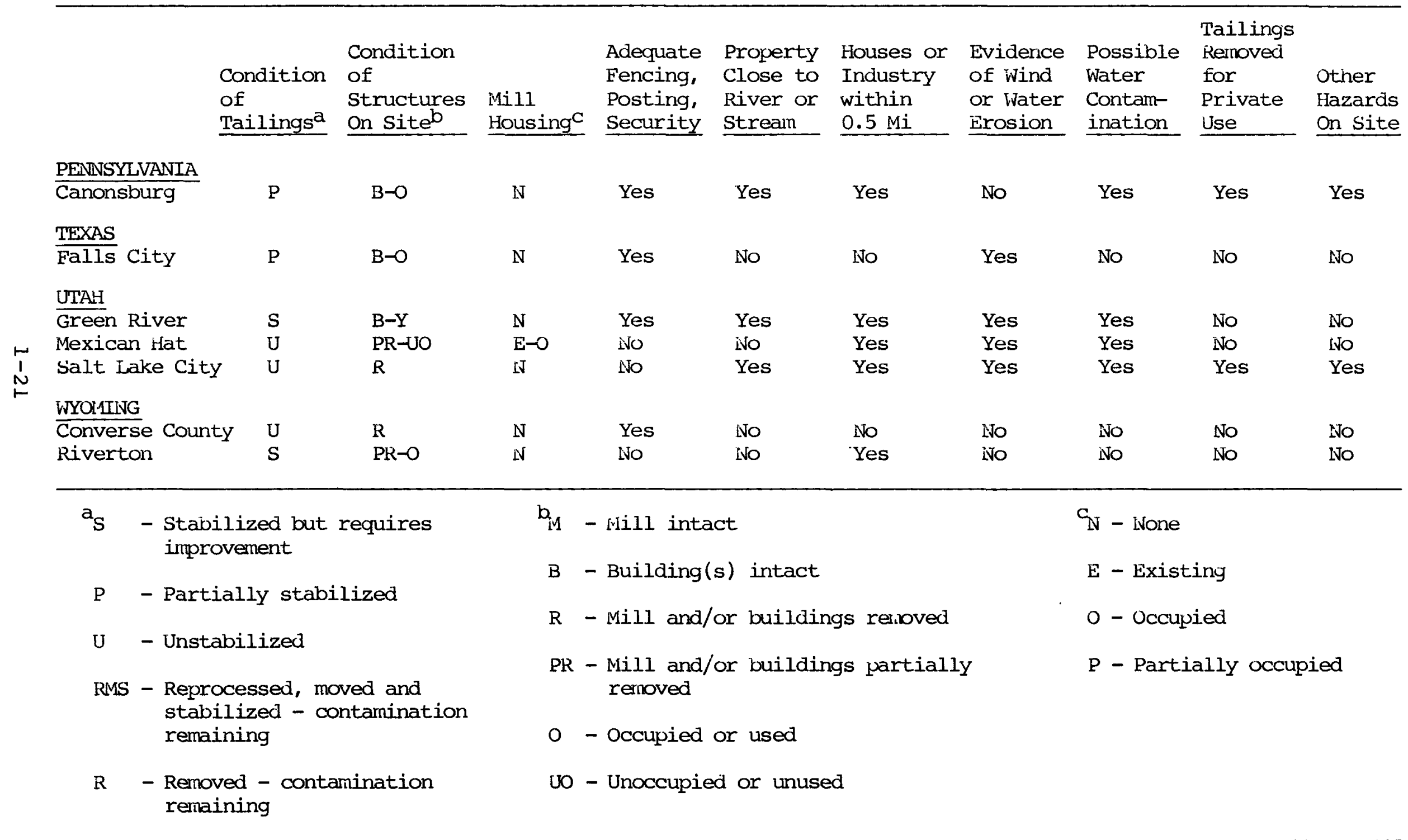


TABLE $1-2$

SUMMARY OF REMEDIAL ACTION OPTIONS AND EFFECTS

\begin{tabular}{|c|c|c|c|c|}
\hline $\begin{array}{l}\text { Option } \\
\text { Number } \\
\end{array}$ & $\begin{array}{l}\text { Site } \\
\text { Specific } \\
\text { Cost } \\
(\$ 000) \\
\end{array}$ & Description of Remedial Action & Benefits & $\begin{array}{l}\text { Adverse } \\
\text { Effects } \\
\end{array}$ \\
\hline I & 710 & $\begin{array}{l}\text { The pile would be stabilized at the bottom } \\
\text { of the open pit with } 3 \text { m of local earth } \\
\text { cover. Watural vegetation would be } \\
\text { established or a riprap cover provided. } \\
\text { on- and off-site contaminated materials } \\
\text { would be cleaned up as necessary. }\end{array}$ & $A-D, G, H$ & $\mathrm{x}$ \\
\hline II & 1,510 & $\begin{array}{l}\text { The tailings, contaminated soil and rubole } \\
\text { would be removed by truck to an unspecified } \\
\text { site located about } 5 \mathrm{mi} \text { from the tailings } \\
\text { site. The tailings site would be decontam- } \\
\text { inated and released for unlimited use. }\end{array}$ & $B-F, H$ & -- \\
\hline III & 1,700 & $\begin{array}{l}\text { Same as option II, except tailings removed } \\
\text { to an unspecified site located about } 10 \mathrm{mi} \\
\text { from the tailings site. }\end{array}$ & $B-F, H$ & -- \\
\hline IV & 1,950 & $\begin{array}{l}\text { Same as Option II, except tailings removed } \\
\text { to an unspecified site located about } 15 \text { mi } \\
\text { from the tailings site. }\end{array}$ & $B-F, H$ & -- \\
\hline
\end{tabular}

Notes

1. All options include on- and off-site remedial action.

2. For Options II through VIII, costs include removal of $3 \mathrm{ft}$ of contaminated earth below the tailings. 
TABLE 1-2 (Cont)

\section{Definition of Benefits}

'A. Access to the tailings site controlled by fencing and posting

B. Off-site windblown tailings cleaned up

C. Wind and water erosion controlled

D. Gamma radiation reduced

E. The source of gamma radiation and radon yas removed from the area

F. No building restrictions on or near site

G. The prime use of the final disposal location unchanged

ii. A reduction in rate of radon exhalation to not more than $2 \mathrm{pCi} / \mathrm{m}^{2}-\mathrm{s}$

Definition of Adverse Effects

x. Limited use of the tailings site 
1. "Summary Report, Phase I Study of Inactive Mill Sites and Tailings Piles"; AEC; Grand Junction, Colorado; Oct 1974.

2. "Phase II - Title I Engineering Assessment of Inactive Uranium Mill Tailings, Spook site, Converse County, Wyoming"; GJT-15; Ford, Bacon \& Davis Utah Inc.; Dec 1977.

3. M.E. Wrenn, H. Spitz, and is. Colen; "Design of a Continuous Digital-output Environmental Radon Monitor"; IEEE Transaction of Nuclear Science; Vol NS-22; Feb 1975.

4. F.F. Haywood, et al.; "Radiological Survey of the Inactive Uranium-Mill Tailings at the spook Site, Converse County, Wyoming"; ORNL-5460; Oak Ridge National Laboratory; Oak Ridge, Tennessee; May 1 y80.

5. H.W. Kraner, G.L. Schroeder, and R.D. Evans; "Measurements of the Effects of Atmospheric Variables on Radon-222 Flux and Soil-Gas Concentrations"; The Natural Radiation Environment; J.A.S. Adams and W.M. Lowder, eds; University of Chicago Press; 1964.

6. Argonne National Laboratory and Ford, Bacon \& Davis Utah Inc.; "Characterization of Uranium Tailings Cover Materials for Radon Flux Reduction"; NUREG/CR-108I (FBDU-218-2); Mar 1980 .

7. "The Effects on Populations of Exposure to Low Levels of Ionizing Radiation"; Report of Advisory Columittee on Biological Effects of Ionizing Radiation; NAS, National Research Council; 1980.

8. B.L. Cohen; "The BEIR Report Relative Risk and Absolute Risk Models for Estinating Effects of Low Level Radiation"; Health Physics; Vol 37, p. 509; 1979.

9. Vital Statistics of the U.S.; Vol II; Mortality; National Center for Health Statistics; HEW; 1908. 


\section{ADDENDUM \\ FIGURES AND TABLES}

(The figures and tables contained on the following pages have been extracted from Chapters 2 through 9 of the parent report.) 


\section{LIST OF FIGURES}

Number

Title

Page

2-1 Aerial Photograph of Site . . . . . . . . . 2-7

2-5 Descriptive Map . . . . . . . . . . . . . 2-11

2-6 Cross-Section Through Pile at Baseline. . . . . 2-12

2-7 Simplified Stratigraphic Column . . . . . . . . 2-13

3-4 Radon Concentration in Vicinity of Pile . . . . 3-22

3-10 EPA Gamrna Survey Surrounding Millsite . . • • 3-28

3-11 Surface and Subsurface Radium Concentrations. . 3-29

3-12 Windblown Contamination Survey. . . . . . . . 3-30

9-1 Area Contanination Plan . . . . . . . . . . . 9-6

Potential Cancer Cases Avoided Per Million
Dollars Expended. . . . . . . . . . . . . . . . . . . 


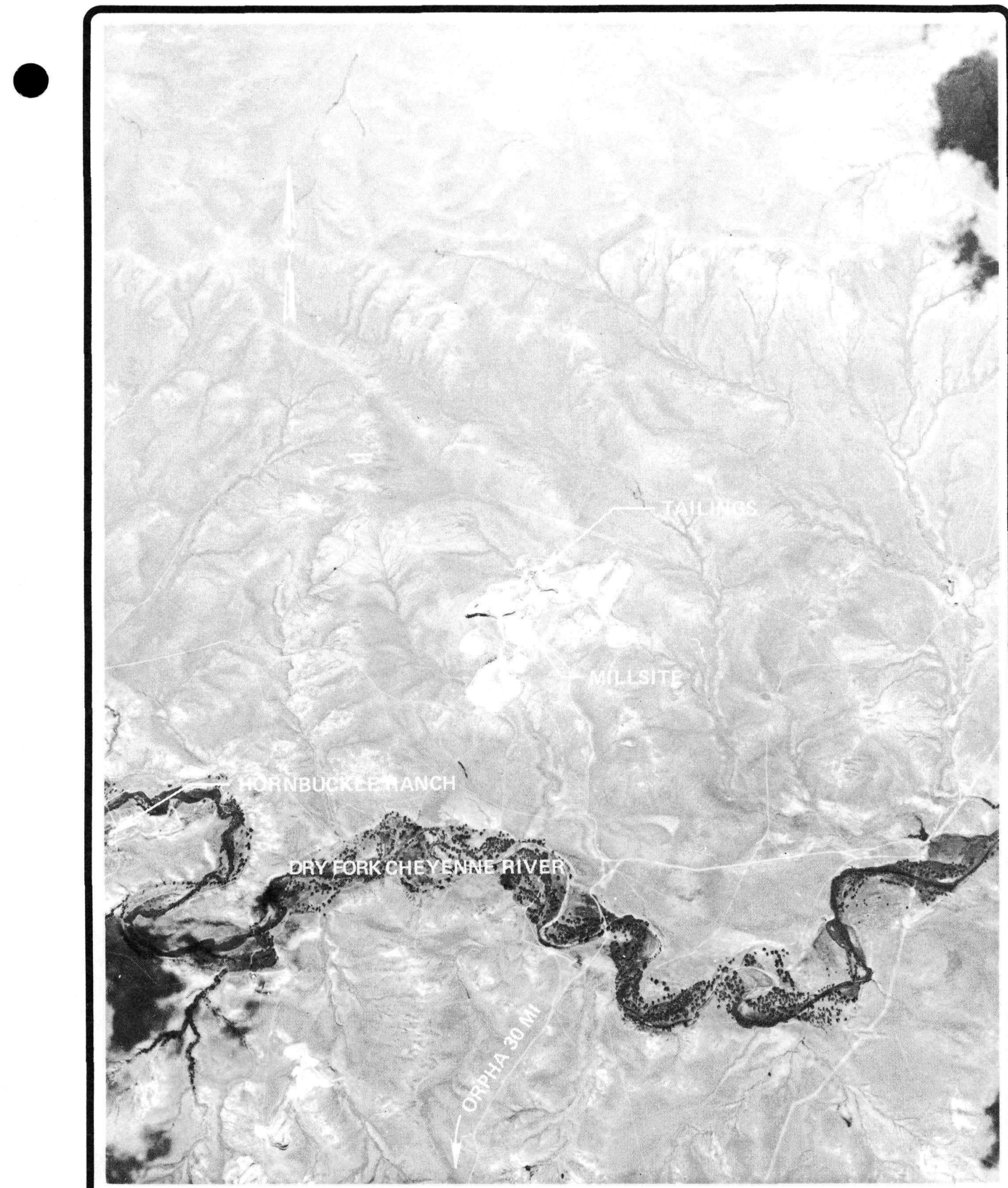

FIGURE 2-1. AERIAL PHOTOGRAPH OF SITE 


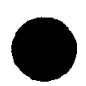

- 


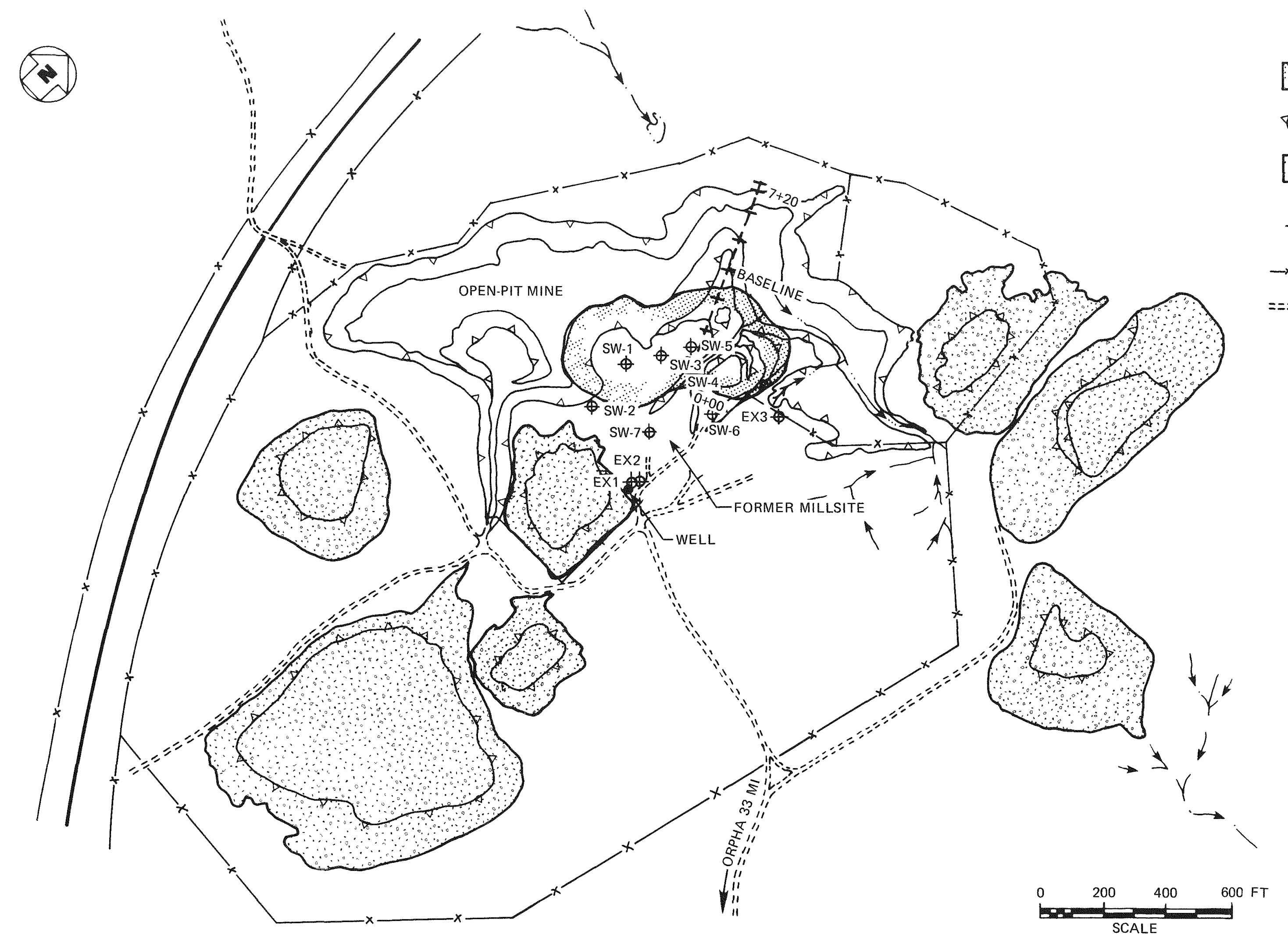

\section{LEGEND}

EDGE OF TAILINGS

SUDDEN CHANGE IN SLOPE (DOWNWARD)

OVERBURDEN AND LOW GRADE ORE PILES FROM OPEN-PIT MINE

EX=EXISTING DRILL HOLE

申 $\quad$ SW=FXISTING DRILL HOLE

- $-x-$ FENCE

$=====$ DIRT ROAD 


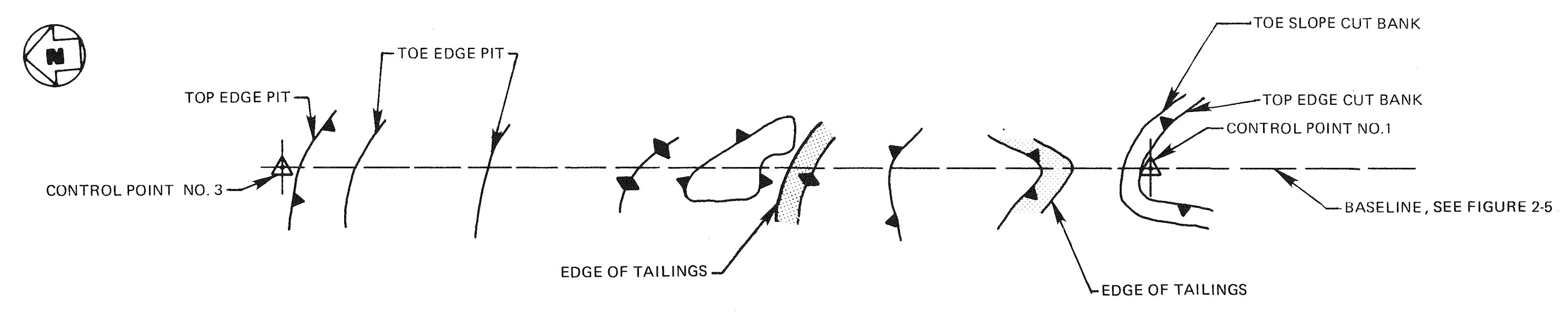

BASELINE

PLAN

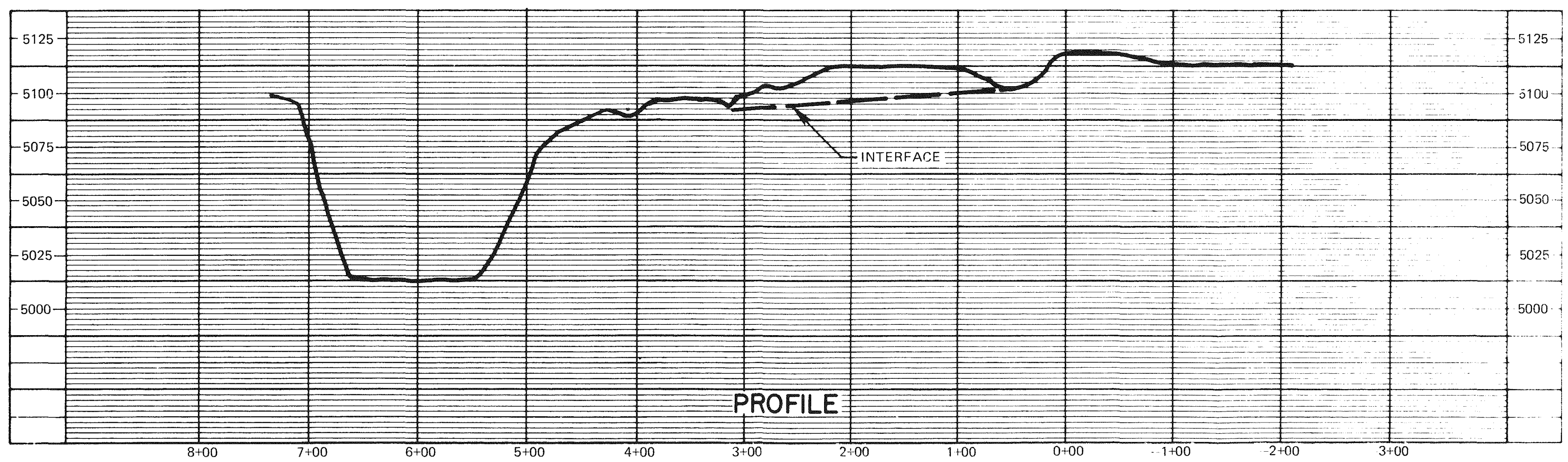

FIGURE 2-6. CROSS-SECTION THROUGH PILE AT BASELINE 
Ford, Sacon \& Davis ytab 3nc.

\begin{tabular}{|c|c|c|c|c|}
\hline SYSTEM & FORMATION & $\begin{array}{l}\text { THICK- } \\
\text { NESS }\end{array}$ & CHARACTER & $\begin{array}{l}\text { POSITION OF } \\
\text { THE TAILINGS }\end{array}$ \\
\hline TERTIARY & $\begin{array}{l}\text { WASATCH } \\
\text { FORMATION } \\
\text { FORT UNION }\end{array}$ & $\begin{array}{c}0- \\
1500 \\
\text { FT } \\
1500- \\
3200 \\
\text { FT }\end{array}$ & $\begin{array}{l}\text { SHALES, SANDSTONES, AND } \\
\text { CONGLOMERATES; FORMS VALLEYS } \\
\text { SLOPES, AND ROLLING HILLS; SANDSTONES } \\
\text { YIELD WATER } \\
\text { SHALES, SANDSTONES, OCCASIONAL COAL } \\
\text { BEDS; FORMS ROLLING HILLS, VALLEYS AND } \\
\text { SLOPES; SANDSTONES YIELD WATER }\end{array}$ & $\begin{array}{l}\text { CONVERSE } \\
\text { TAILINGS } \\
+\end{array}$ \\
\hline \multirow{4}{*}{ CRETACEOUS } & $\begin{array}{l}\text { LANCE } \\
\text { FORMATION }\end{array}$ & $\begin{array}{l}1000- \\
2900 \\
F T\end{array}$ & $\begin{array}{l}\text { SHALES WITH SOME SANDSTONE UNITS } \\
\text { AND OCCASIONAL COAL BEDS; FORMS } \\
\text { VALLEYS AND SLOPES; AQUICLUDE }\end{array}$ & \\
\hline & $\begin{array}{l}\text { FOX HILLS } \\
\text { SANDSTONE }\end{array}$ & $\begin{array}{l}125- \\
300 \\
\text { FT }\end{array}$ & SANDSTONES; FORM BENCHES; AQUIFER & \\
\hline & $\begin{array}{l}\text { LEWIS SHALE } \\
\text { FORMATION }\end{array}$ & $\begin{array}{l}1150 \\
F T\end{array}$ & $\begin{array}{l}\text { DARK GRAY MARINE SHALE; FORMS } \\
\text { VALLEYS AND SLOPES; AQUICLUDE }\end{array}$ & \\
\hline & $\begin{array}{l}\text { MESAVERDE } \\
\text { FORMATION }\end{array}$ & $\begin{array}{l}500 \\
\text { FT }\end{array}$ & $\begin{array}{l}\text { BUFF SANDSTONES WITH INTERBEDDED } \\
\text { SHALES; FORMS BENCHES, RIDGES, AND } \\
\text { CLIFFS, AQUIFER }\end{array}$ & \\
\hline \multicolumn{4}{|c|}{ OLDER SEDIMENTARY ROCKS } & \\
\hline
\end{tabular}




\section{LIST OF TABLES}

Number

Title

$\underline{\text { Page }}$

3-4 Chemical Analyses of Converse County Water Samples $(\mathrm{rng} / 1) . . \cdot . \cdot . \cdot . \cdot . \cdot . \cdot 3-38$

9-1 Summary of Stabilization and Disposal Costs... . . . . . . . . . . . . . . . . 9-8

9-2 Potential Cancer Cases Avoided and Cost Per Potential Case Avoided. . . . . . . . . 9-9 
Ford, Macon \& Davis tab anc.

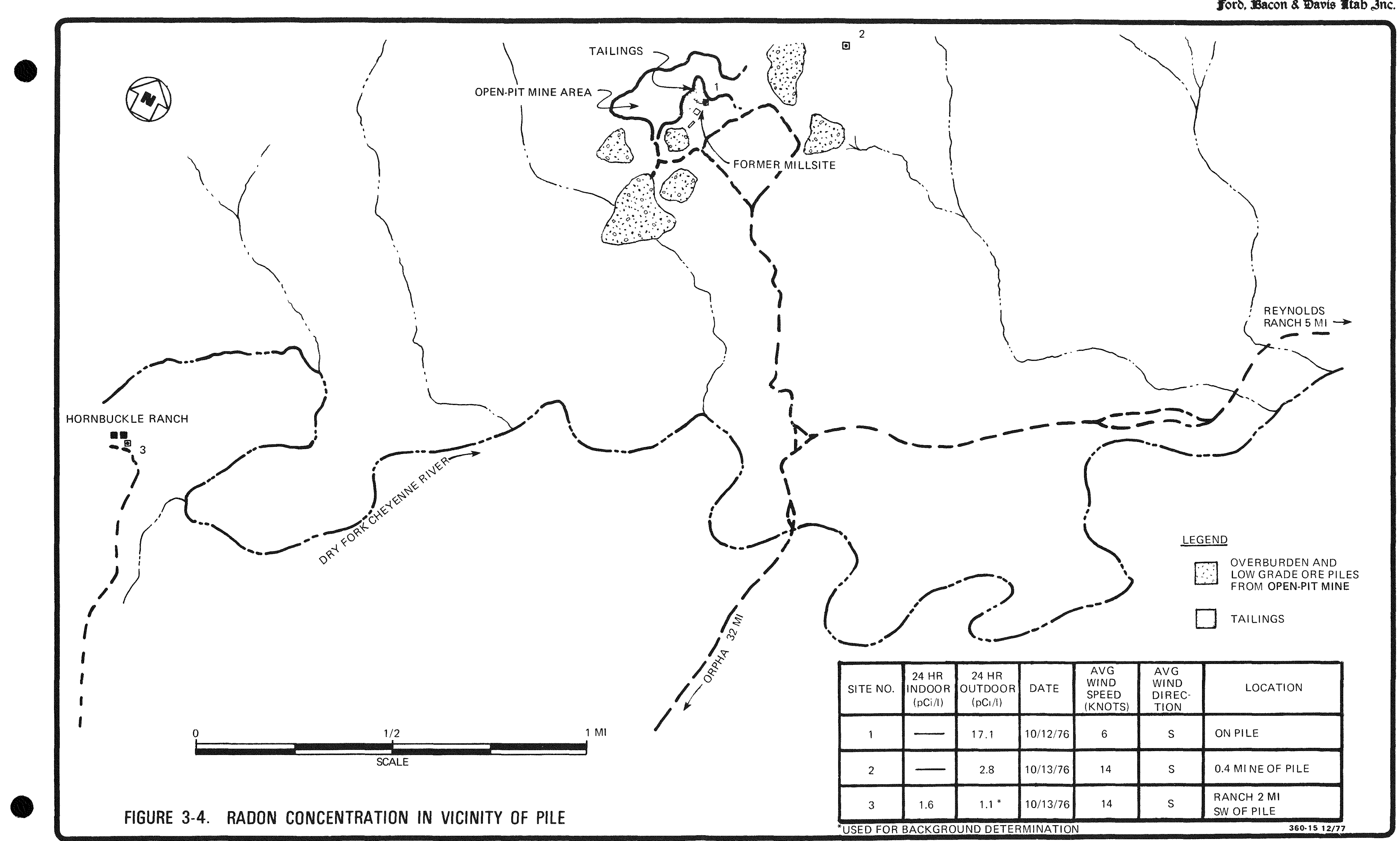


Jford, Jacon \& Davis litab anc
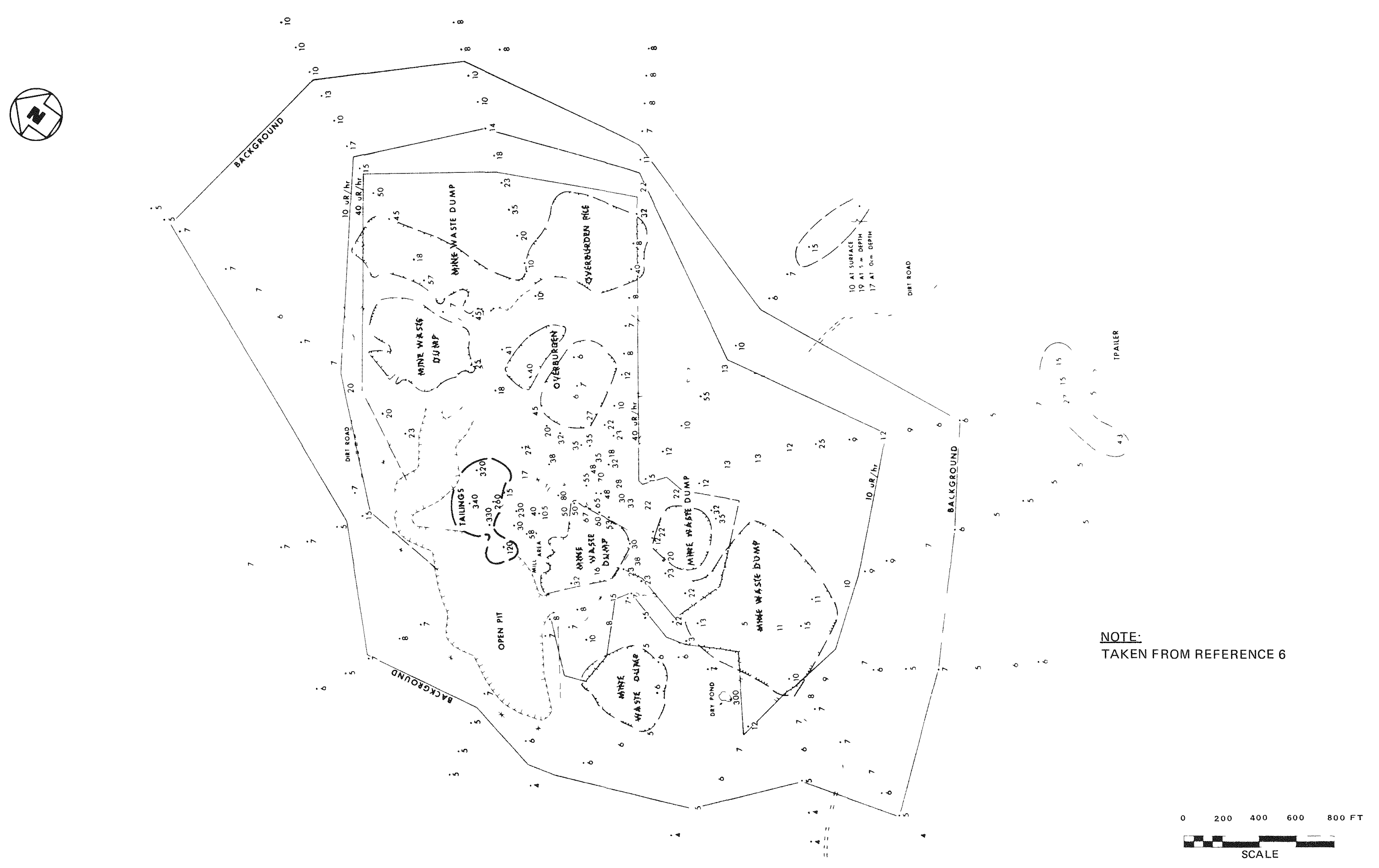


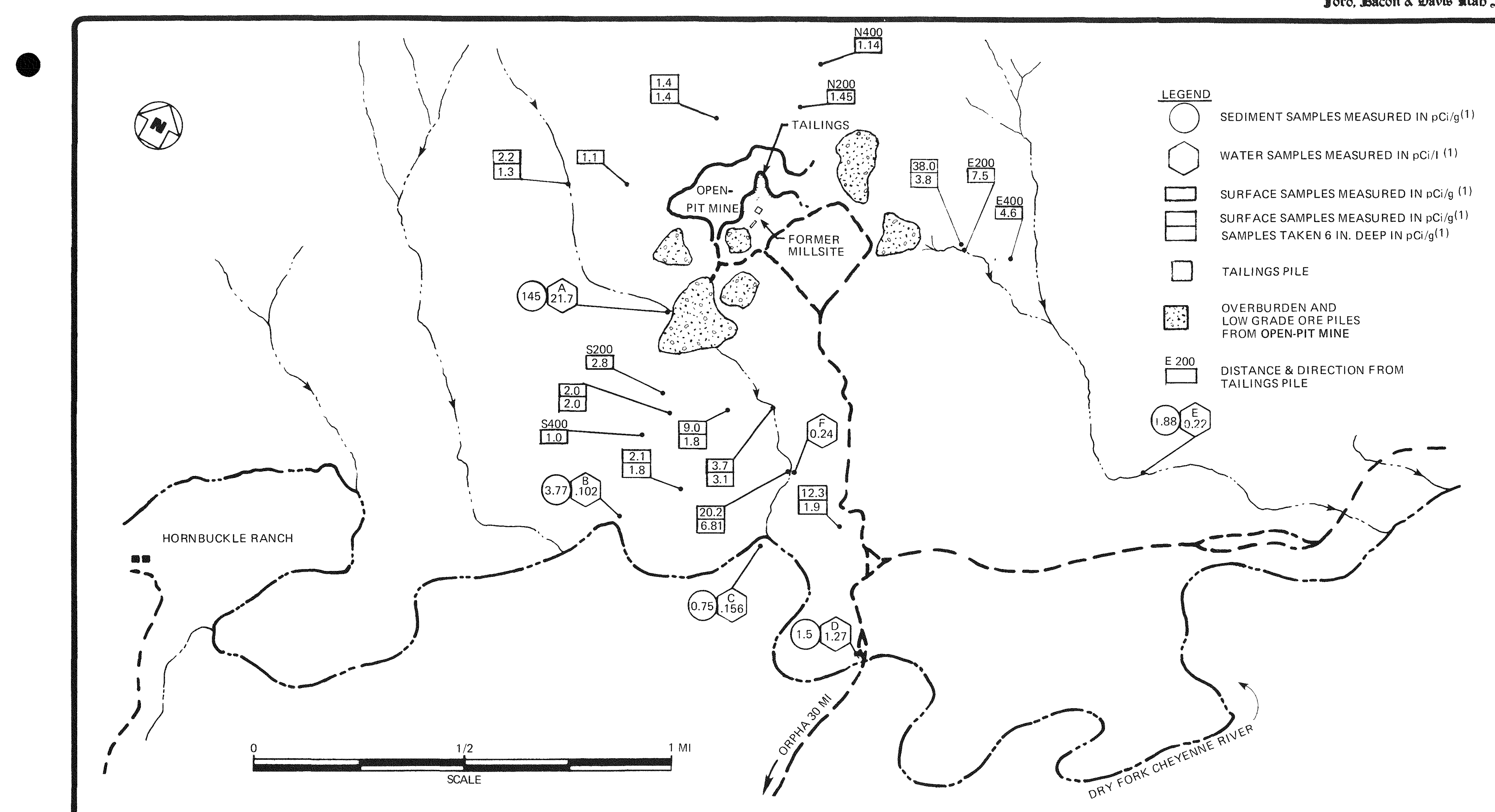



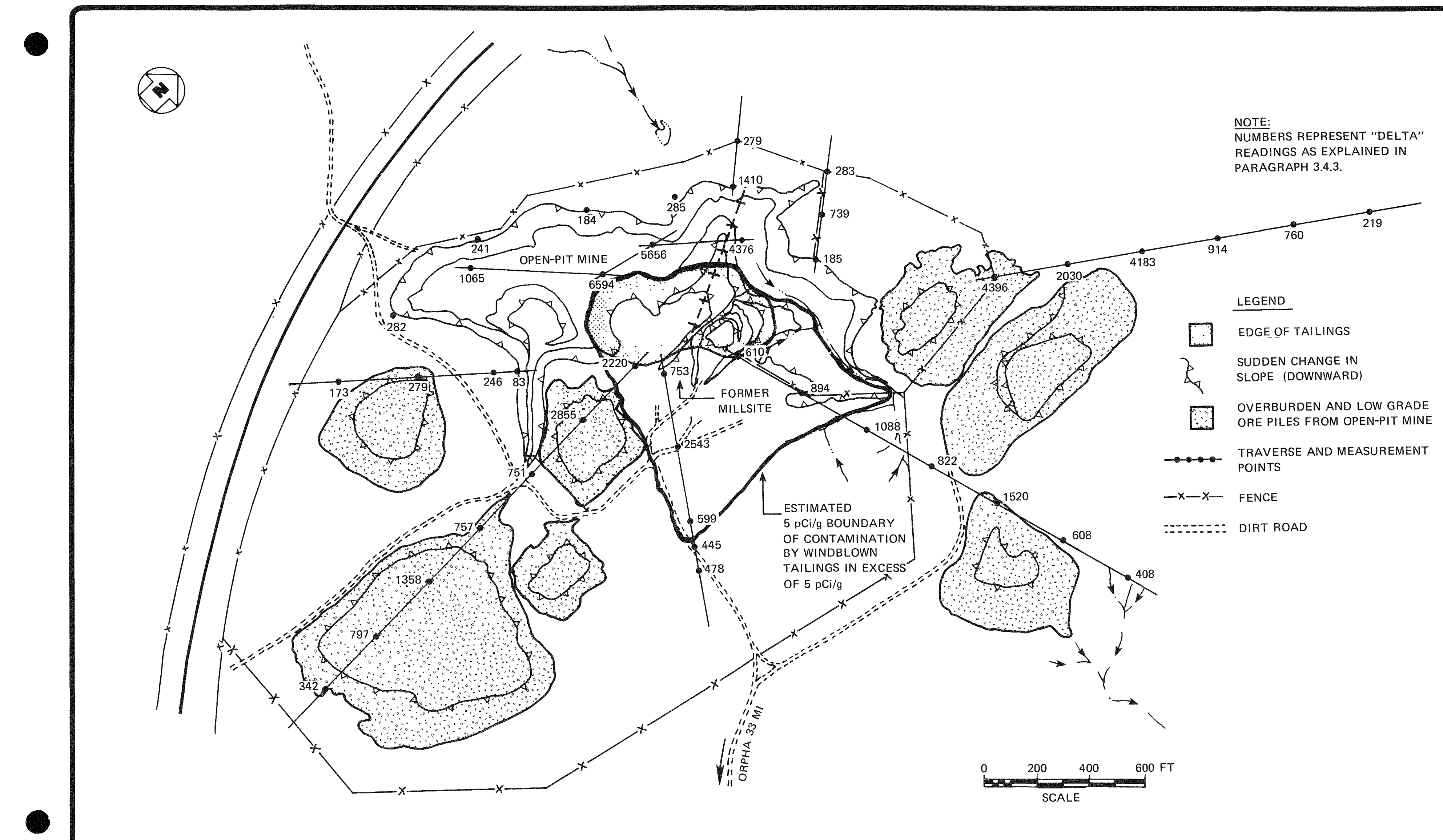
TABLE 3-4

CHEMICAL ANALYSES OF CONVERSE COUNTY WATER SAMPLES (mg/1)

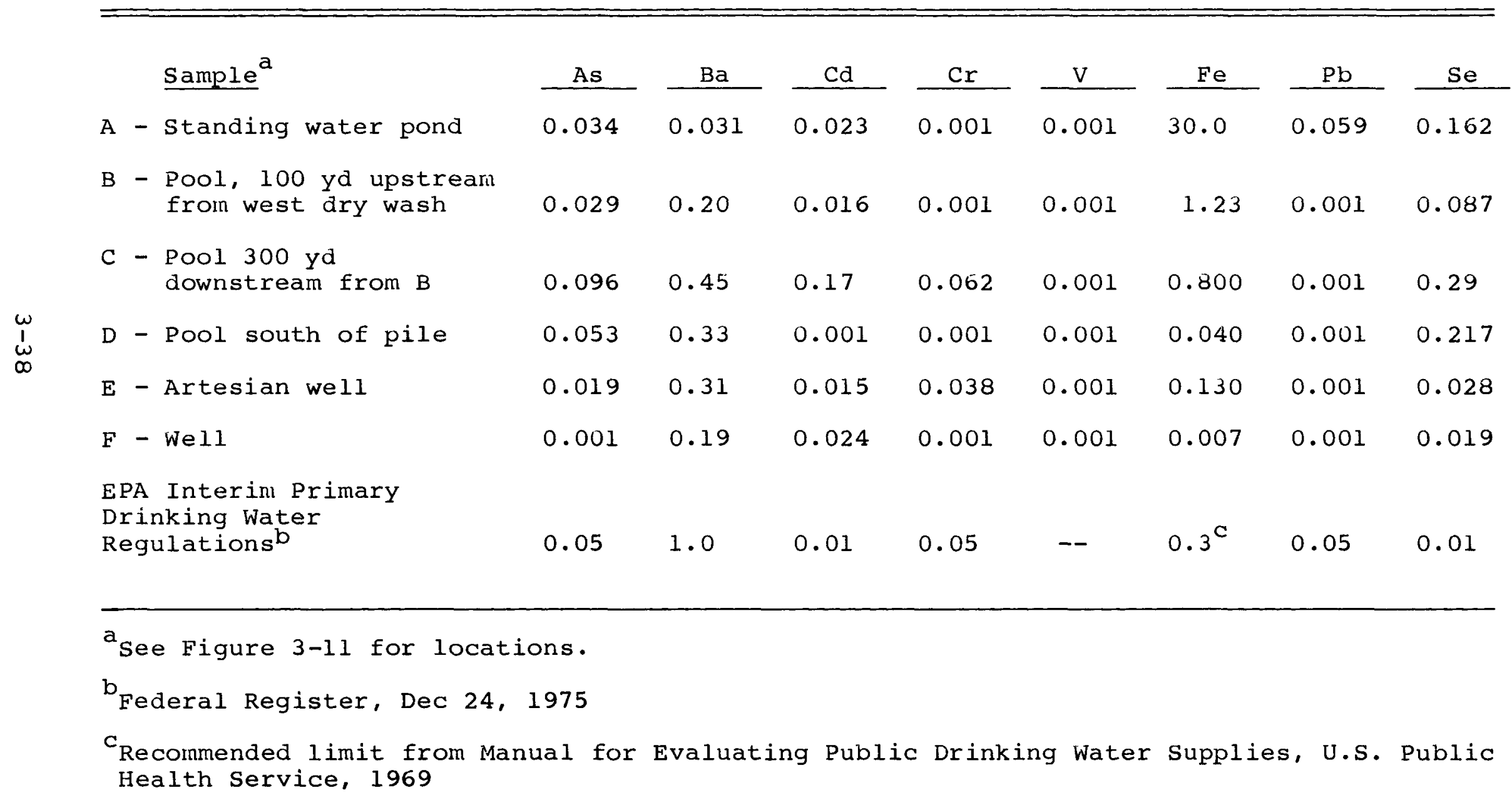


(e)

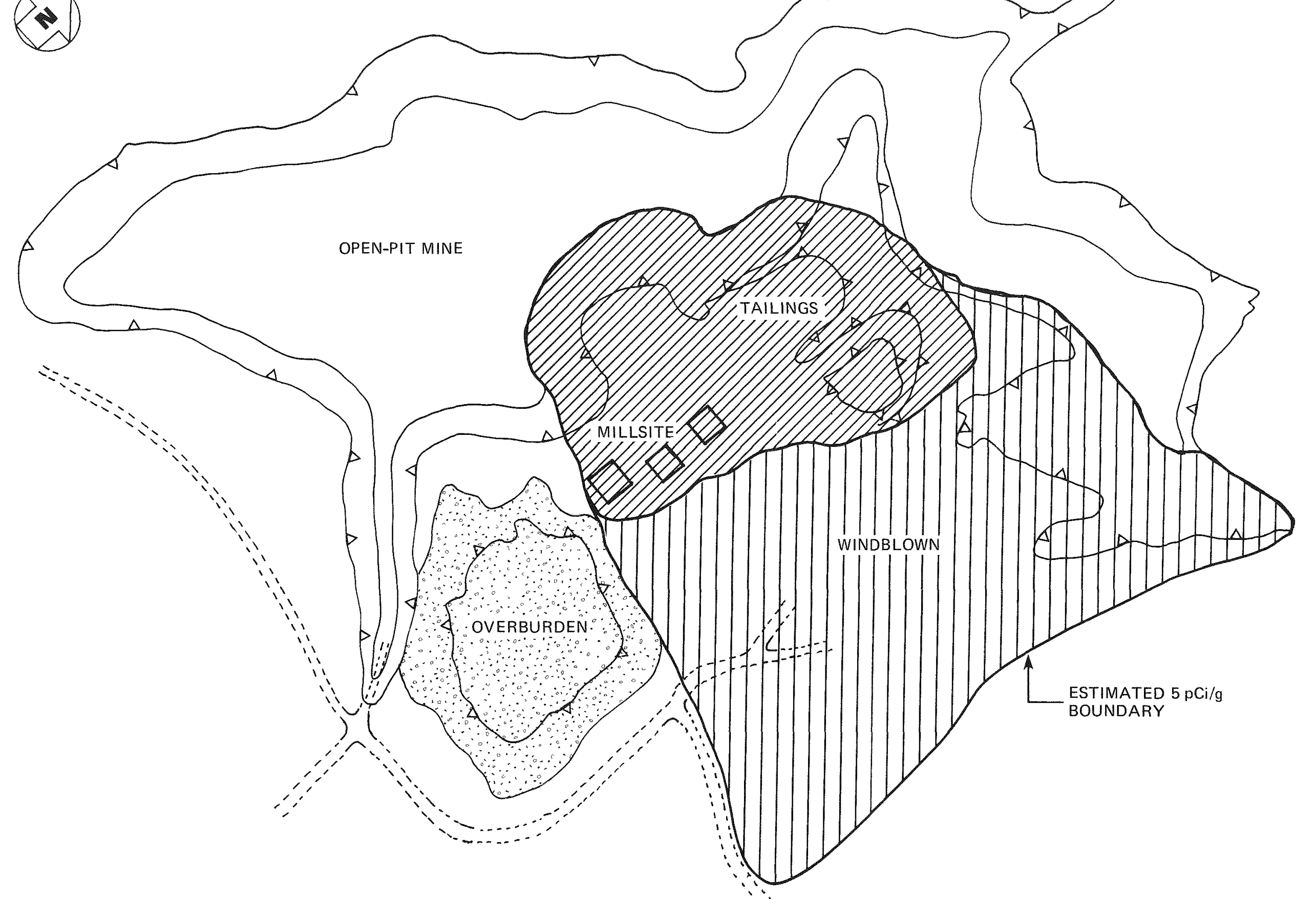

ASSUMED DEPTHS OF REMOVAL

DA 2 FT OF SUBSURFACE TO

[1] $\begin{gathered}\text { GIN. OF MATERIAL TO } \\ \text { BE REMOVED }\end{gathered}$ 


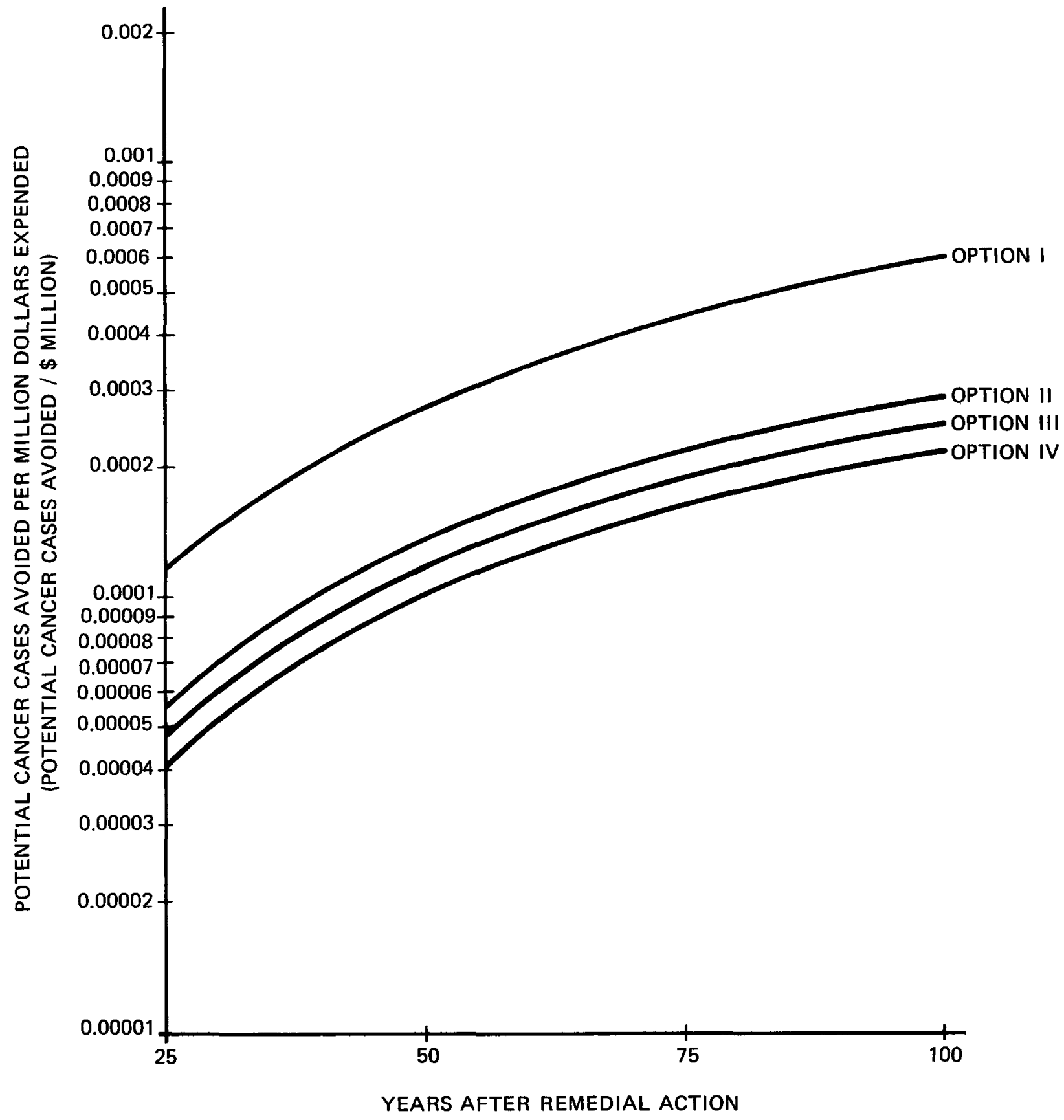

FIGURE 9-2. POTENTIAL CANCER CASES AVOIDED PER MILLION DOLLARS EXPENDED 
TABLE 9-1

SUMMARY OF STABILIZATION AND DISPOSAL COSTS ${ }^{a}$

\begin{tabular}{|c|c|c|c|c|c|}
\hline & & $I$ & II & III & IV \\
\hline 2 . & Off-Site other than Windblown & -- & -- & -- & -- \\
\hline 3 . & Off-Site Windblown & 50 & 50 & 50 & 50 \\
\hline 4 . & $\begin{array}{l}\text { a. Capital Costs } \\
\text { b. Haul Costs }\end{array}$ & -- & $\begin{array}{l}100 \\
260\end{array}$ & $\begin{array}{l}105 \\
390\end{array}$ & $\begin{array}{l}110 \\
570\end{array}$ \\
\hline 5 . & Disposal Site & -- & 390 & 390 & 390 \\
\hline & $\begin{array}{l}\text { Total cleanup } \\
\text { (sum of lines } 1 \text { through } 5 \text { ) }\end{array}$ & 420 & 950 & 1,100 & 1,280 \\
\hline 8. & $\begin{array}{l}\text { Total } l^{b} \\
(\text { sum of lines } 6 \text { and } 7)\end{array}$ & 550 & 1,160 & 1,310 & 1,500 \\
\hline 9. & $\begin{array}{l}\text { Contingency } \\
(308 \text { of line } 8)\end{array}$ & 160 & 350 & 390 & 450 \\
\hline 10 & $\begin{array}{l}\text { GRAND TOTAL } \\
\text { (sum of lines } 8 \text { and } 9 \text { ) }\end{array}$ & 710 & 1,510 & 1,700 & 1,950 \\
\hline
\end{tabular}


TABLE 9-2

PO'TEN'TIAL CANCER CASES AVOIDED

AND COST PER POTENTIAL CASE AVOIDED

\begin{tabular}{|c|c|c|c|c|c|c|c|}
\hline \multirow[b]{2}{*}{ Options: } & iNumber & of & Potential & 1 Cancer & Cases & \multicolumn{2}{|c|}{ s Avoided } \\
\hline & & & I & II & & III & IV \\
\hline $\begin{array}{l}\text { Option Cost } \\
\text { (million } \$ \text { ) }\end{array}$ & & & 0.71 & 1.5 & & 1.7 & 2.0 \\
\hline \multicolumn{8}{|l|}{$\begin{array}{c}\text { Years After } \\
\text { Remedial } \\
\text { Action }\end{array}$} \\
\hline $\begin{array}{r}25 \\
50 \\
75 \\
100\end{array}$ & & $\begin{array}{l}<0 \\
<0 \\
<0 \\
<0\end{array}$ & $\begin{array}{l}.000083 \\
.00020 \\
.00032 \\
.00043\end{array}$ & $\begin{array}{l}0.000083 \\
0.00020 \\
0.00032 \\
0.00043\end{array}$ & & $\begin{array}{l}.000083 \\
.00020 \\
.00032 \\
.00043\end{array}$ & $\begin{array}{l}0.000083 \\
0.00020 \\
0.00032 \\
0.00043\end{array}$ \\
\hline
\end{tabular}

B. Cost Per Potential Cancer Case Avoided (Million \$)

$\begin{array}{lcrrr}\begin{array}{l}\text { Options: } \\ \text { Option Cost } \\ \text { (milion } \$ \text { ) }\end{array} & \text { I } & \text { II } & \text { III } & \text { IV } \\ \text { Years After } & 0.71 & 1.5 & 1.7 & 2.0 \\ \text { Rernedial } & & & & \\ \text { Action } & & & & \\ & & & & \\ 25 & >8,554 & 18,072 & 20,482 & 24,096 \\ 50 & >3,550 & 7,500 & 8,500 & 10,000 \\ 75 & >2,219 & 4,688 & 5,313 & 6,250 \\ 100 & >1,651 & 3,488 & 3,954 & 4,651\end{array}$

